\title{
And how will you remember me, my child? Redefining fatherhood in Turkey
}

Gary Barker

Deniz Dogruoz

Debbie Rogow

Follow this and additional works at: https://knowledgecommons.popcouncil.org/departments_sbsr-pgy

Part of the Demography, Population, and Ecology Commons, Family, Life Course, and Society Commons, Gender and Sexuality Commons, Gender Equity in Education Commons, International Public Health Commons, and the Sociology of Culture Commons How does access to this work benefit you? Let us know!

\section{Recommended Citation}

Barker, Gary, Deniz Dogruoz, and Debbie Rogow. 2009. "And how will you remember me, my child? Redefining fatherhood in Turkey," Quality/Calidad/Qualité no. 19. New York: Population Council. 
And How Will You Remember Me, My Child? Redefining Fatherhood in Turkey

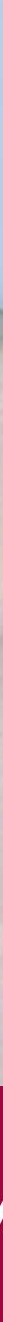




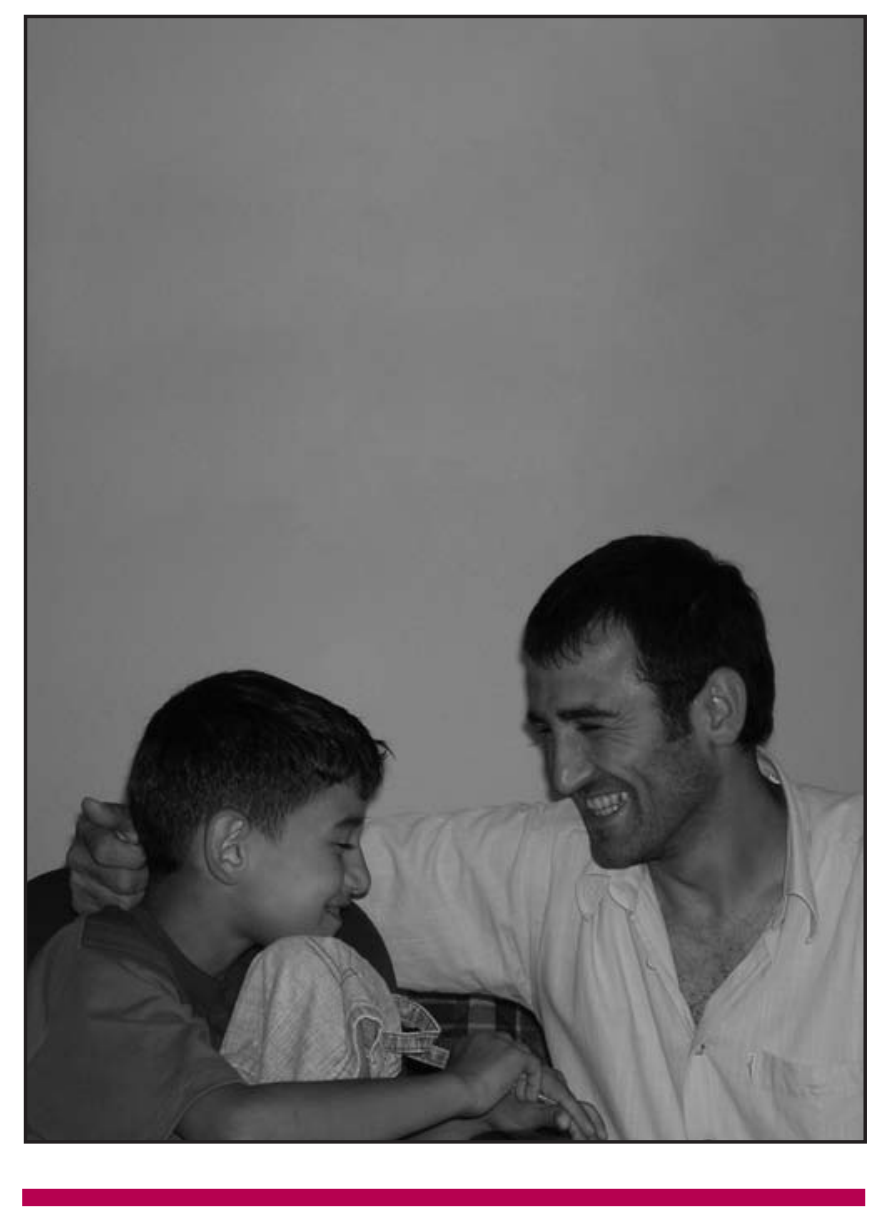

And How Will You Remember Me, My Child? Redefining Fatherhood in Turkey 
Quality/Calidad/Qualité, a publication of the Population Council, presents case studies of high-quality, innovative programs in sexual and reproductive health. $Q / C / Q$ specifically documents educational and clinicbased programs that are making strides in one or more of the following ways: (1) addressing the central importance of gender dynamics in shaping sexual and reproductive health outcomes; (2) improving the quality of care of clinic-based services; and (3) reaching disadvantaged and underserved groups. With rare exceptions, featured programs are operating in developing countries.

$Q / C / Q$ case studies — selected by an expert advisory group - are offered not as mod- els for replication, but as examples for learning. They demonstrate a responsiveness to broader social and economic transformations; they highlight inventive and affordable ways to respond to clients' needs; and they reflect the self-critical and flexible attitude required for learning from program experiences and research evidence. Although they are written as practical tools -in accessible style with carefully selected detail-they also serve to inspire program leaders and policymakers to enable clients to become more effective guardians of their sexual and reproductive health, and by doing so contribute fundamentally to the achievement of such broader aims as the Millennium Development Goals.

\section{Production Staff}

Editor: Debbie Rogow

\section{Assistant Editor and Production Coordinator: Michelle Skaer}

Copyeditor: Karen Tweedy-Holmes

Designer: Mike Vosika

Translators: Xavier Gonzales (Spanish) and Genevieve Haines (French)

\section{Advisory Committee}

$\begin{array}{ll}\text { Delia Barcelona } & \text { Laura Laski } \\ \text { Gary Barker } & \text { Ann Leonard } \\ \text { Carmen Barroso } & \text { Ann McCauley } \\ \text { Judith Bruce } & \text { Liz McGrory } \\ \text { Batya Elul } & \text { Manisha Mehta } \\ \text { Susana Galdos } & \text { Suellen Miller } \\ \text { Françoise Girard } & \text { Saumya Ramarao } \\ \text { Nicole Haberland } & \text { Ann Starrs } \\ \text { Katherine Kurz } & \text { Cynthia Steele }\end{array}$

\section{(2) Population Council}

Publication of this edition of Quality/Calidad/Qualité is made possible by support provided by the Ford Foundation and by the Poverty, Gender, and Youth Program of the Population Council. Statements made and views expressed in this publication are solely the responsibility of the authors and not of any organization providing support for $Q / C / Q$.

The Population Council—an international, nonprofit, nongovernmental organization-focuses on HIV and AIDS; poverty, gender, and youth; and reproductive health.

Population Council, One Dag Hammarskjold Plaza, New York, NY 10017 USA

tel: (212) 339-0500 fax: (212) 755-6052 e-mail: qcq@popcouncil.org http://www.popcouncil.org

Cover photograph by Debbie Rogow.

Issue No. 19 ISSN: 1097-8194

Copyright (C) 2009 The Population Council, Inc.

Any part of this publication may be copied or adapted to meet local needs without permission from the Population Council, provided that the parts copied are distributed free or at cost (not for profit) and that the source is identified. The Population Council would appreciate receiving a copy of any materials in which the text is used. 


\section{Introduction}

\section{Fatherhood: The Low-Hanging Fruit}

\section{by Gary Barker}

In discussions of how to engage men in promoting gender equality, we have started with sexual and reproductive health, moved to HIV/AIDS prevention, and then on to engaging men in efforts to prevent gender-based violence. Only recently have we discovered the low-hanging fruit: men's roles in the lives of their children. Fatherhood (and men's roles in the lives of children in general) is an ideal starting point for engaging men in gender equality for two key reasons.

First, most men want to be involved in the lives of children, whether their own biological children, or younger siblings, nieces, or nephews. Pictures of men playing with and caring for babies and children make most of us-men included-feel good. Men report that their relationships with children are a major source of happiness and meaning in their lives. Men have tremendous self-interest in being involved in the lives of children.

Second, responsibility for the care of children is at the heart of gender inequality. Women are the principal providers of care for children and for others in the home. To give some examples: In Guatemala, men spend about a third of the time that women do in caring for children (Alatorre 2002). In the United States, fathers' availability to their children increased from about onehalf of that of mothers in 1980s to nearly two-thirds of that of mothers in the 1990s (NCOFF 2002). In Brazil, men in twoparent families spend just 77 percent of the time that mothers do in childcare activities (Benetti and Roopnarine 2006). This imbalance is one of the main engines of gender inequality and is directly associat- ed with women's lower wages and limited advancement relative to that of men in the workplace.

Outside the home as well, women are the main providers of paid childcare and represent the majority of primary-level teachers in much of the world. Such work is generally accorded relatively low status and salary. The fact that boys and girls from

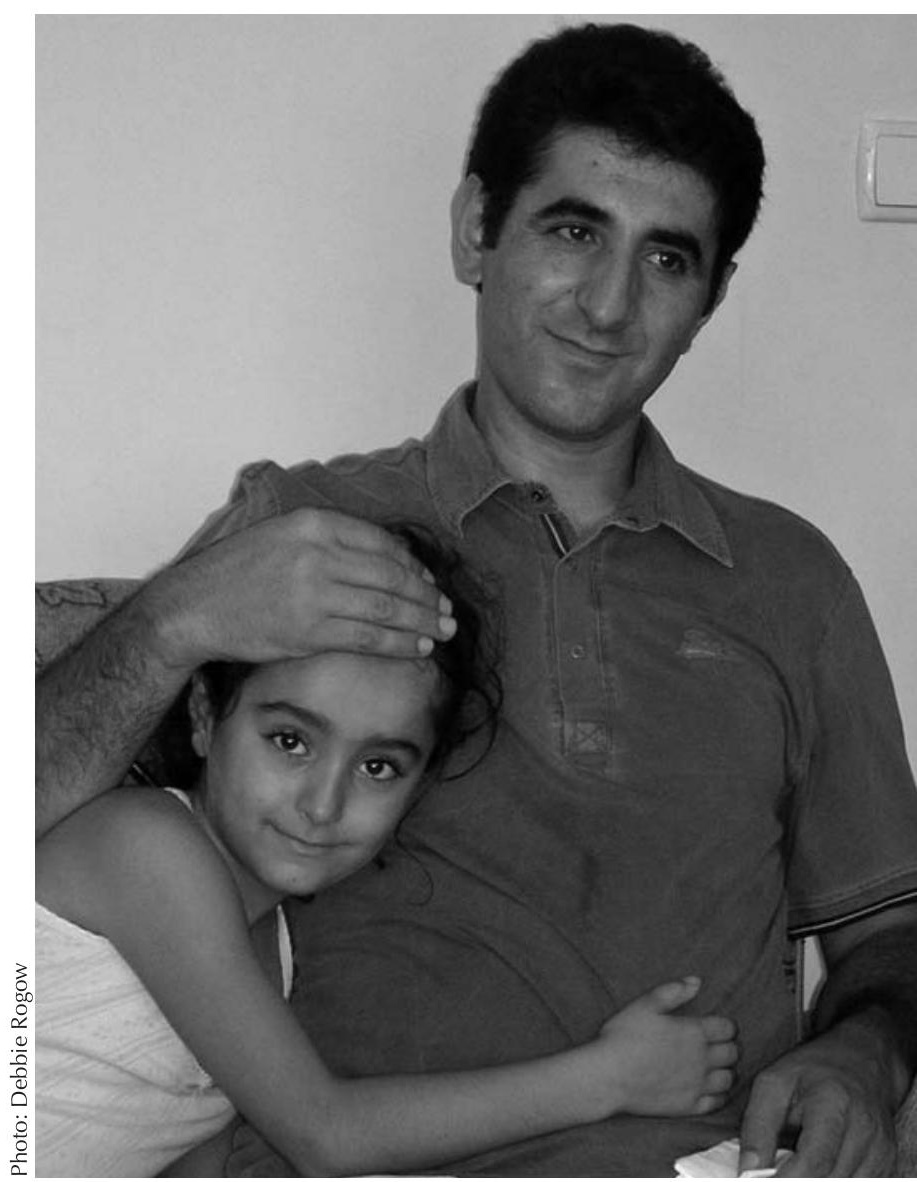

Fatherhood (and men's roles in the lives of children in general) is an ideal starting point for engaging men in gender equality. 
their earliest years see women and girls (whether mothers, female relatives, or female day-care workers) as their caretakers perpetuates rigid and inequitable social norms related to caregiving.

Change - as we see in this case study — is happening. But change is uneven, too slow, and stressful. In a new world order where

\section{As more women enter the} workforce, both women and men may feel confused about fathers' roles, asking "Do men really know how to care for children?"

more women work outside the home, both women and men may feel confused over fathers' roles within the family.

We often hear this question from men, women, and even children: Do men really know how to care for children? One study conducted in the Caribbean found that boys (and girls) rarely see a man in a teaching or caring profession before they reach secondary-school level. In much of the world, the belief is widespread that men do not know how to care for children, or that if men have more contact with young children, there will be greater risk for physical and sexual abuse of children (Medrado 1998).

This case study reports on a program initiated in Turkey, where women are increasingly a presence in the workforce. The Mother Child Education Foundation, AÇEV, provides educational and social support to help fathers assume a more positive and engaged role with their children. AÇEVlike fathering programs in other countries-has found that many men want to be more involved caregivers. They seek paternal fulfillment beyond serving as the disciplinarian and moral guardian and beyond engaging in occasional playtime with their children. When provided with information and with opportunities to express doubts and develop skills (how to change diapers, how to seek health care for a child, and how to talk constructively with children about their feelings), we see that men are

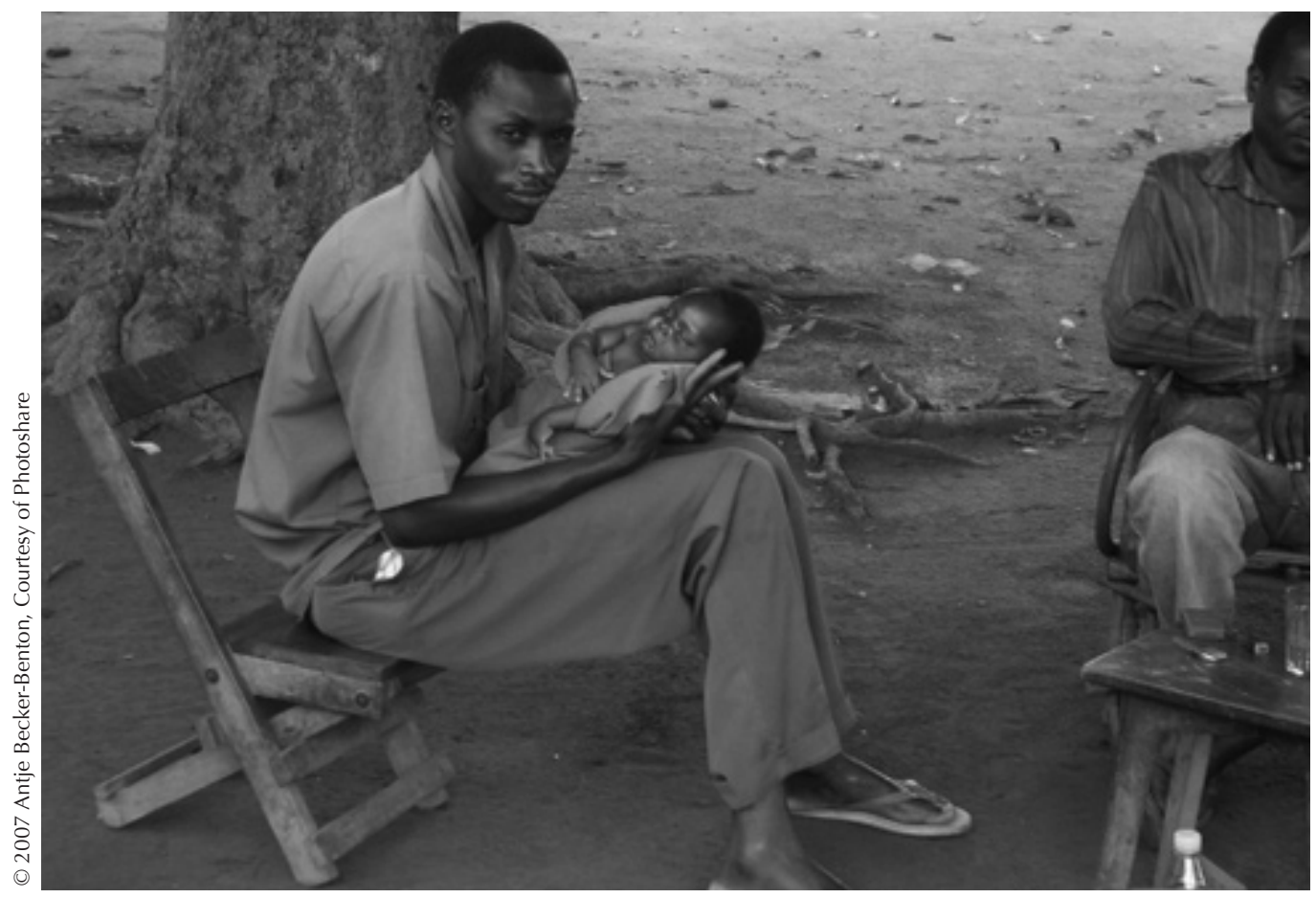




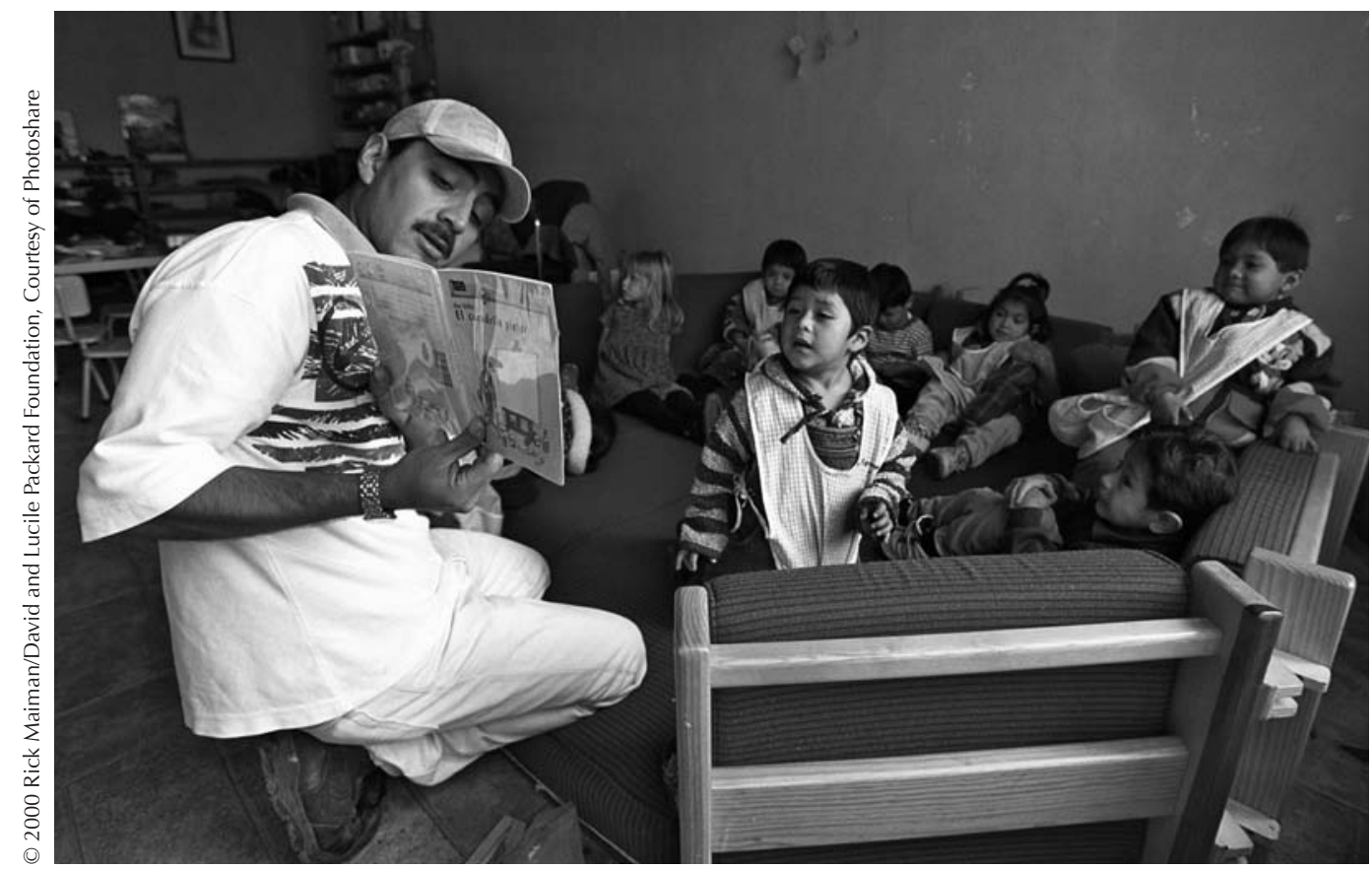

Children who see and experience men as caregivers in day-care centers or schools are more likely to view such caregiving as part of the male role.

\section{References}

Alatorre, J. 2001. Iniciativa para la Paternidad Responsible en el Istmo Centroamericano. Mexico: United Nations Economic Commission for Latin America and the Caribbean (CEPAL).

Alatorre, J. 2002. Paternidad Responsible en el Istmo Centroamericano. Mexico: United Nations Economic Commission for Latin America and the Caribbean (CEPAL).

Benetti, S. and J. Roopnarine. 2006. "Paternal involvement with school-aged children in Brazilian families: Association with childhood competence." Sex Roles 55(9/10): 669-678.

Costa, M., L. Lima, D. Júnior, C. Santos, F. Araújo, and D. Assis. 2005. "Adolescent pregnancy and paternal co-responsibility: Socio-demographic background and attitudes towards the pregnancy and the child." Sciência e Saúde Coletiva 10(3): 719-727.
Levine, J.A. 1993. "Involving fathers in Head Start: A framework for public policy and program development." Families in Society: The Journal of Contemporary Human Services 74(1): 4-19.

Medrado, B. 1998. "Homens na arena do cuidado infantil: Imagens veiculadas pela mídia." In Homens e Masculinidades: Outras Palavras. Eds. M. Arilha, S. Ridenti, and B. Medrado. São Paulo: Ed. 34/ ECOS. Pp. 15-30.

National Center on Fathers and Families (NCOFF). 2002. "The Fathering Indicators Framework: A Tool for Quantitative and Qualitative Analysis." Philadelphia: NCOFF.

Russell, G. and M. Radojevic. 1992. "The changing role of fathers? Current understandings and future directions for research and practice." Infant Mental Health Journal 13(4): 296-311. 


\section{And How Will You Remember Me, My Child? Redefining Fatherhood in Turkey}

by Deniz Doğruöz and Debbie Rogow

Yusuf Akhan was making a life for himself in Istanbul. The grandson of a shepherd, Yusuf had left school to work at 13 and eventually became a barber. He was providing for his wife and young son's basic needs. But he felt something was missing.

One evening, Yusuf attended a meeting at the local school where someone introduced the "Father Support Program." He explains why "it was exactly right for me . . . just what I was looking for."

Myown father fullfilled his role as a father by bringing home food and protecting us. To him, that was fatherhood. But we lacked love. He did not play with us or spend time with us. He would beat my mother and us. I don't undervalue or disrespect him, but it made me feel some kind of weakness-that somehow, one has no power.

And I had become a version of my father. Not exactly like him, but a kind of copy. My father could not express his emotions, his caring. I was the same. This is something I knew was a problem.

Yusuf enrolled in the program, offered by the Mother Child Education Foundation of Turkey (AÇEV), a nonprofit organization that also offered extended education and support groups to mothers. Together with 16 other young fathers, he participated in 13 weekly sessions, led by an AÇEV-trained facilitator. Yusuf readily describes what he learned:

I learned to let my children play freely, to let them fall or spill things. Our group leader said, "Let them play - things that get dirty can be cleaned." Even their games are important for their development, for example, a child develops cognitive and motor skills through games.

The one thing that was most important in the program for me was learning communication methods, such as "active listening." My son likes to be listened to, and sometimes he says, "Listen to me!" (Smile.) Sometimes he annoys us all with his talking, but we now say "Okay, let him talk!" A child needs attention. If you build good communication, you can have good relationships. Problems can be solved by listening, by spending time.

"My father could not express his emotions, his caring. I was the same. This is something I knew was a problem."

You can teach kids proper behavior, but you can explain it to them in a correct way. For example, we had difficulty training our son in the habit of washing his hands and brushing his teeth. I asked myself, "How can I make him wash his hands?" I thought a photo-cell faucet (that turns on in response to an object in front of it) would make it fun, so we installed it in the sink, and now he uses it. Now I take him to the supermarket and he picks out his own toothbrush. Later, if he doesn't like it, we tell him, "You picked it!" 


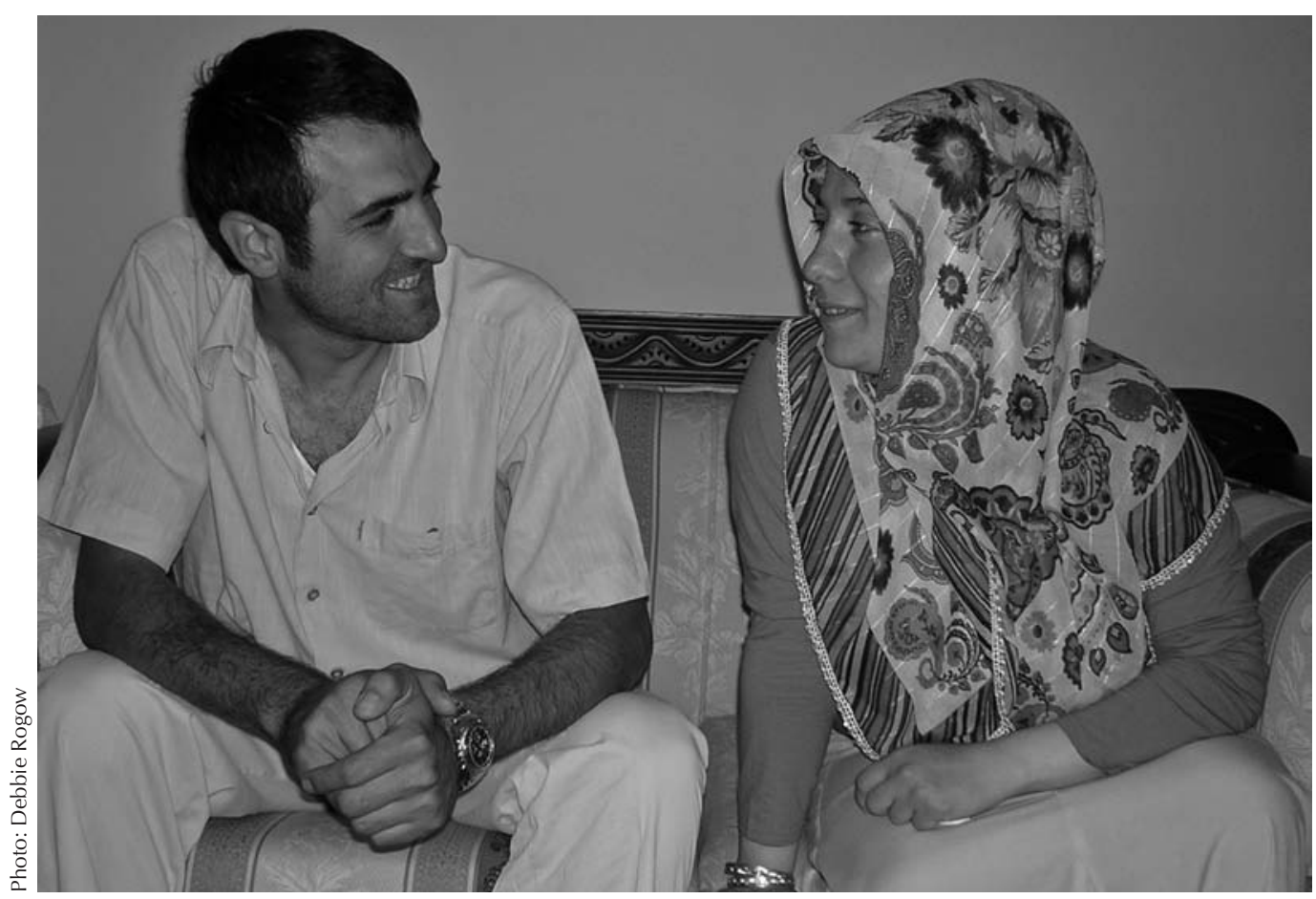

"I needed to allocate time to my wife and child. I started to see and feel: Something is about to change," reflects Yusuf, shown here with his wife.

I needed to allocate time to my wife and child. I started to see and feel: Something is about to change. Then my child started to talk a lot to me. A lot. And he noticed I was listening. Now, I try to show my son the love, attention, and care that I lacked from my own father.

As a single anecdote, Yusuf's experience would be poignant, but his reflections are echoed by thousands of fathers across Turkey who are "graduates" of the Father Support Program. Indeed, to assist in developing this case study, dozens of fathers took time from their jobs or came back early from their holidays and welcomed us into their homes. Each of them explained that their experience had been so meaningful that they believed that fathers everywhere should have the same opportunity that they had enjoyed. This case study reports on the origins of the Father Support Program, on the efforts and setbacks encountered in its establishment, on the results to date, and on lessons learned.

\section{Fatherhood and Men's Roles in Turkey}

Around the world, children grow up feeling much the same as Yusuf-respecting and loving their fathers but longing for affection, attention, and understanding. For their part, fathers, too, often wish for closer and more caring relationships with their children. However, few men-despite lingering disappointment about their relationships with their own fathers-have a sense of another way to be or have the skills to overcome their inadequate socialization in relating to their children. Expectations about manhood and fatherhood are reinforced from one generation to the next. Across social classes, fathers' roles are defined narrowly as breadwinners and disciplinarians; fathers are not expected to participate actively in child rearing. Women continue to bear most of the burden of household responsibilities so that men can socialize outside the home; in Turkey, men 
typically gather in coffeehouses when they have leisure time.

In Turkey, as elsewhere, present-day social and economic trends have brought tensions surrounding "archetypal" fathering to the surface. Changing gender norms and the increasing numbers of women in the workforce create pressure for men to share more equitably in domestic and childcare responsibilities. From 1996 to 2006, the national female literacy rate increased from 72 percent to 82 percent (Zahir 2006). The need for both parents to share equitably in childcare has become even more acute as young families increasingly live apart from their extended families. All of these trends are accelerated by migration patterns: In Turkey, 35 percent of the rural population has moved to cities in the past two decades. Turkey's urban population in 1990 was 59 percent; it had increased to 68 percent by 2003, according to the Turkey Demographic and Health Survey (Hacettepe University Institute of Population Studies 2004).

Parenting groups exist in Turkey for young mothers. Until the late 1990s, however, no such opportunities were available for a young father like Yusuf, who knew he wanted to do better by his child but needed a supportive environment for learning about himself and the needs of his young son. As it turns out, Yusuf is far from alone.

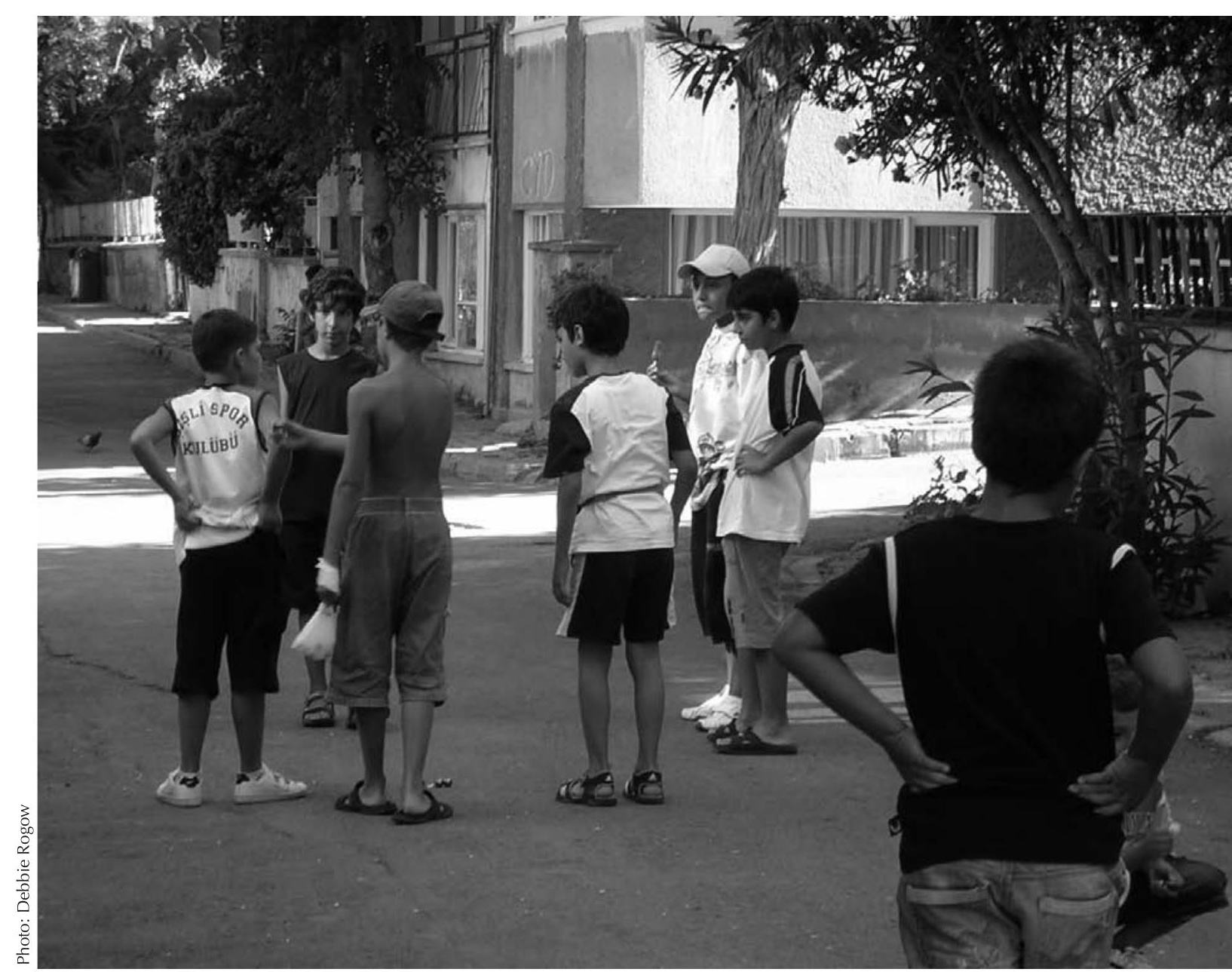

Expectations about manhood and fatherhood are reinforced from one generation to the next. 


\section{AÇEV Launches the Father Support Program}

The Turkish name for the Mother Child Education Foundation is Anne Çocuk Egitim Vakfı, hence its acronym AÇEV (pronounced $\mathrm{AH}$-Cheff). The foundation, a highly respected nongovernmental organization based in Istanbul, has been serving women and families nationwide since 1993. Its aim is to empower people through early education and family literacy programs, early childhood education programs, and women's empowerment groups (see box below). The organization works primarily in lower-income communities across Turkey.

\section{Mothers Set Off the Spark}

The idea for a program for fathers came from women who were attending a 25-session mothers' support group run by AÇEV. These women were learning a lot about child development and parenting, but they still encountered problems at home with child rearing. According to AÇEV cofounder, board member, and university professor Sevda Bekman:

The women were happy with the Mother Support Program but found the fa- thers to be the obstacles. The husbands were not supporting what the women had learned. The mothers kept telling us, "We need a project for fathers!" They wanted their husbands to learn as well and to become more involved.

According to Bekman, no one knew quite how to respond. There was reluctance within the Foundation to undertake a program for fathers. Some argued that the foundation's key strategy was to support families specifically through mothers. They doubted that fathers would participate; they would not have the time or interest, and such a program would conflict with their perception of their roles as household heads and breadwinners.

Over time, it became clear that AÇEV's mission required the participation of fathers. As Sevda Bekman recalls, "We had a theoretical perspective that placed the child in a context, and the mother and child are only two members of this context. The father needed to be involved. In a patriarchal society, this was hard to think about. But we had to think about it." Happily, the Chair of AÇEV's Board at the time, Aysen Özyegin, was open to innovation and planted the seeds for Turkey's first program aimed at supporting fathers.

\section{AÇEV's Other Programs}

\section{Mother Child Education Program}

This program provides mothers of six-year-olds with knowledge and tools for fostering the cognitive development of their children. It reaches about 15,000 mothers every year.

\section{Women's Empowerment and Integrated Literacy Program}

This 14-week intensive literacy and empowerment program strengthens functional literacy skills while raising awareness of issues such as women's human rights, legal rights, women's and children's health, communication, positive discipline, gender equality, and children's/ girls' rights. To date, approximately 80,000 women in ten provinces have participated.

\section{Preschool Parent-Child Education Program}

This nine-session program, based at state-run preschools, prepares parents to support the development of their children's preliteracy and prenumeracy skills. The program reaches more than 2,000 parents annually.

\section{Intensive Summer Preschools}

This nine-week program provides summer enrichment programs for five-to-six-year-olds living in extremely poor neighborhoods around the country. To date, AÇEV has offered more than 240 summer preschool classes. 


\section{The Goal}

The goal of the Father Support Program is a broad one: for fathers to play a more effective and positive role in the development of their children. For AÇEV staff, this enhanced role requires that fathers recognize their own importance in their children's emotional lives, that they spend time with them, engage in activities together, talk and play with them, and care for them as part of ensuring that their children feel safe, secure, loved, and happy.

The program built upon the strong sense of paternal responsibility in Turkish culture, but to the father's "job description" it added social and psychological support to his recognized economic and moral roles. The planning committee decided to focus on literate fathers with children between the ages of two and ten.

\section{Getting Started}

AÇEV's experience working with mothers provided a strong technical foundation for establishing a parallel program for fathers. As Sevda Bekman explains, "We knew how to support parents with regard to child development and about child-rearing responsibilities and parenting skills. We had a programmatic structure." The initial funding was allocated from AÇEV's core budget, which drew from Board support. ${ }^{1}$

Bekman's help was instrumental in establishing the new program. The planning stage involved consultation with staff from the Mother Support Program, with various fathers, and with psychologists and other experts. An initial written plan-with objectives, an operating model, and a plan for funding and recruitment-was circulated and discussed. Bekman says this process led to several revisions of their initial ideas. For example, one decision was to make the program for fathers shorter than the 25-session series for mothers.
The objectives were for fathers to:

- realize their own importance in child development;

- gain knowledge about child development and apply it to establishing developmentally appropriate expectations of their children;

- learn methods of positive discipline and avoid engaging in abusive behavior toward their children;

- feel supported in playing a more effective role in their child's development;

- establish a shared responsibility between parents for child rearing; and

- learn and apply communication and problem-solving skills.

Achieving these objectives was expected to foster democratic culture and harmony, not only within the family but also in the broader network of fathers' social relations.

\section{Staffing Up}

The initial team consisted of a program coordinator and education specialist. Serkan Kahyaoglu, a consultant in adult education and counseling, worked closely with the team. The staff members worked with Board Member Sevda Bekman to launch the program-developing an overall plan, a training-of-trainers workshop, written materials, and a strategy for recruiting facilitators for the support groups and fathers to participate. From the beginning, Serkan-who argued that "the most important thing is teamwork" - helped establish a democratic culture within the Father Support Program; he felt that the principles of openness and mutual respect that the program was aiming to foster among fathers should be practiced among staff as well and in the content and process of training group leaders.

Over time, the Father Support Program has evolved, but the early core principles continue to guide the program.

\footnotetext{
1 Board Members Hüsnü and Aysen Özyegin have provided significant leadership and financial support to the organization, including to the implementation of the Father Support Program.
} 


\section{Recruiting and Training Group Leaders}

Since 1993, AÇEV had been recruiting group facilitators for its program for mothers. To find people to lead groups for fathers, they went to the teachers' union, which helped recruit guidance counselors and teachers from primary schools. As Derya Akalın, AÇEV's General Manager since 2000, explains: "This strategy had two advantages. First, the individuals we were recruiting were already skilled educators. Second, as school professionals, they were in an excellent position to recruit fathers (of students at their schools) to participate."

The training of trainers (TOT) to become group leaders covers all the topics that are discussed with fathers, and builds the skills leaders need to organize and conduct the groups. The TOT is characterized by several features:

Intensity: The training is a ten-day residential workshop. Participants learn the use of interactive teaching methods, as well as techniques to encourage them to share their experiences. Emphasis is placed on building group cohesion, because the bonds among the fathers are an important ingredient of program impact and success. The trainers also prepare the new group leaders to recruit fathers and to plan activities that keep them involved. Derya Akalın is clear about the level of commitment required:

We aim to achieve both attitude and behavior change. So we make an intensive investment in program staff and trainers. These are teachers who are used to dealing with young children, and now they will deal with adults, sometimes older adults. It takes voluntarism, for the amount of money [they earn as leaders] is almost funny; it barely covers anything.

Interactive Participation: The entire workshop is conducted in an interactive, experiential manner. The ten days are filled with games, discussions, role playing, and small-group work. As school counselors,

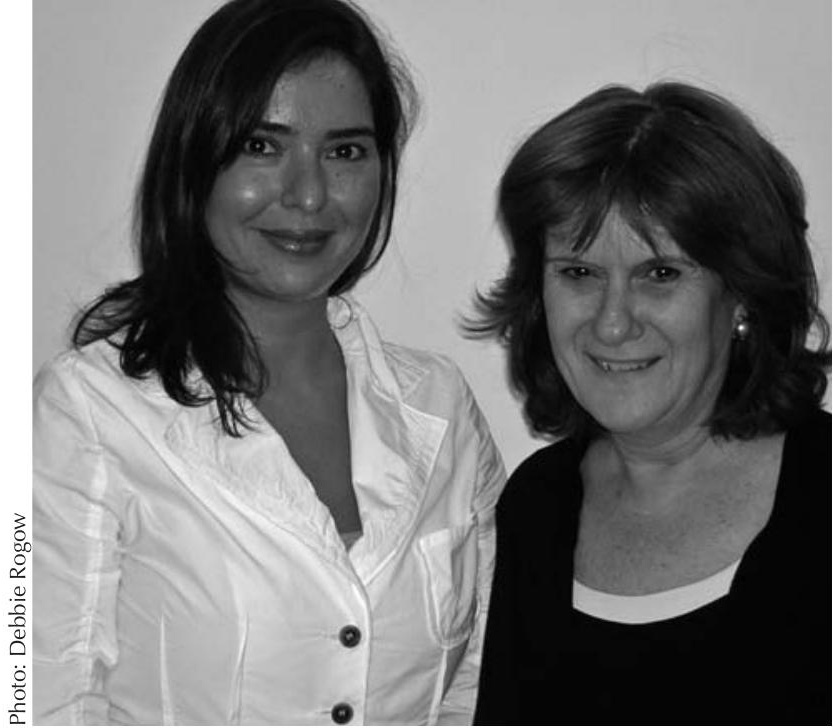

AÇEV's General Manager Derya Akalın and Board Member Sevda Bekman.

many of the participants are already aware of the importance of dialogue; in a teaching context, however, they are far more accustomed to didactic methods. The trainees later rely on these same interactive methods and activities in working with fathers.

Focus on Emotional Themes: The participants explore the same issues that they will be addressing when they become group leaders. Although some of these issues are more factual than others (for example, the role of play in child development), many emphasize emotional issues-including trainees' feelings about their own fathers, responding to children without anger, caregiving, and children's feelings and emotional needs. Trainees are encouraged to share their experiences with each other and to work together in trying to find solutions to their problems.

Specificity: The trainees receive a highly detailed manual that provides them with everything they need to run each session with the fathers, including a script and handouts for each lesson plan. This manual both supports the group leader and ensures standardization of the program.

Teamwork and Democracy: As part of modeling respect and democratic culture for fathers and families, the trainers establish a nonhierarchical relationship with the professionals who are their trainees. Relating in this way provides a model for 
the participants to follow when they start their own groups with fathers. As Serkan Kahyaoglu reflected:

We may design a lesson plan about anger that we believe is perfect, but then the trainer tells us that it did not have the desired effect. If we tell the group leader that he did not understand the lesson plan, then he will also learn to say, "I applied it correctly but the fathers did not understand it." The most important thing is for people to be able to share their thoughts and feelings openly in an appropriate way, including with the child at home. We must be open to feedback; the feedback mechanism is part of what we teach. Our main purpose is to create an atmosphere of openness that can carry over to the family. (For a discussion of how the program approaches gender issues, see page 26).

As the current Program Coordinator, Hasan Deniz, states:

The selection process is most important, and the recruitment has been refined over and over as we try to identify the most effective group leaders and coop- erating institutions. That the group leaders are volunteers means that they believe in the program. There is a kind of Darwinism in our selection - those who remain are the most fit for the program!

Of course, given the sometimes sensitive content, the degree of engagement, and the diversity of participants from across the political spectrum, a lively controversy sometimes erupts in the discussions. Staff explain that the trainees bring different values to the sessions and sometimes have open conflicts, for example, about child rearing; they see these conflicts as presenting the possibility of productive interaction.

Two current group leaders reflected on their experience in the TOT:

The TOT gave us concrete steps that were easy for me to apply. Sharing in the group, hearing from others about their experiences, enriched me. Now I experience being a group leader as a two-sided opportunity.

$$
\text { -Olcayto Ezgin }
$$

My friends told me about the Father Support Program. It added to my profession and life-long learning, but also to my life.

- Sami Erdogan

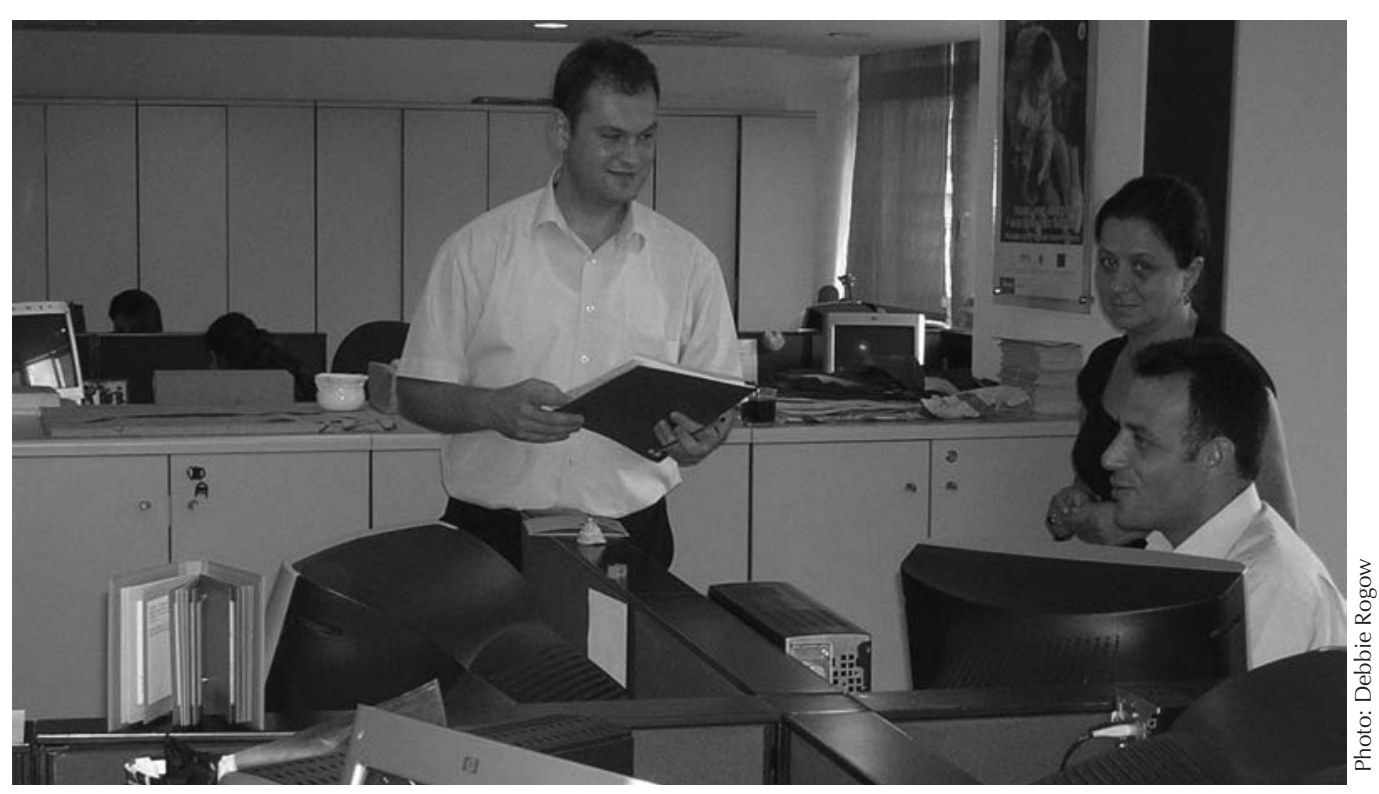

AÇEV's program staff were compelled to respond to mothers who were clamoring for a program to educate their husbands. Pictured above are Deniz Doğruöz, Aysen Akgül, and Hasan Deniz. 


\section{Pilot, and Pilot Again}

After training group leaders and establishing informal cooperative arrangements with the teachers' union, AÇEV organized several pilot series in the group leaders' primary schools serving mostly lower- and middleincome families. These pilot activities allowed the staff to refine a number of program elements.

A 13-Session Series: Initially, staff had designed a five-session program. Both the group leaders and the fathers who attended the pilot group agreed that more sessions were necessary. The curriculum was ex-

\section{"My father was not an educated}

man. Our relationship was based

on trust, love, and kindness ... I

have seen fathers and sons, and

I wished inside that the father

could just listen to his son. That is

why I am here."

- Hasan Deniz,

program coordinator

panded to 12 sessions, then to 15 , and eventually settled at 13, where it remains. Each session lasts two to two and a half hours.

Male Group Leaders: Staff were not sure if fathers would respond better to a male or female group leader. Sevda Bekman laughs, recalling: "We had two groups: one led by a woman, one by a man." Attendance at the female-led group declined significantly, but increased during the course of the male-led group. Therefore, the decision was made that the groups for fathers would be run by men.

Avoiding Hierarchy: As part of instilling a democratic, minimally hierarchical culture in the program, the staff decided to rename the trainers or teachers as "group leaders."

Targeting Literate Fathers of Young Children: AÇEV organized a range of early groups, that varied widely in terms of fathers' income levels and the ages of their children. Most were held at schools and aimed at parents of young students, but some were offered for workers at a glass factory. The program was found to be most effective among men who were literate and whose children were between two and ten years old. The program continued to emphasize school-based outreach.

Support Materials for Wives and Children: Many men were trying to share what they were learning with their family members. In some cases, this sharing resulted in their lecturing or scolding their wives for parenting styles that diverged from what the fathers were learning. Providing free materials for wives and children allowed the men to engage their families in a supportive way.

A Detailed Manual for Group Leaders: The program manual was rewritten in simpler language, with everyday examples. Substantive changes were also made, particularly with regard to gender issues. According to Serkan Kahyaoglu, "We had to emphasize more clearly that there is not a difference between boys and girls, and also that fathers must communicate democratically with their wives." The result was an extremely detailed manual that provides exact directions-almost a scriptfor running each of the 13 sessions.

Sevda Bekman admits that the transition beyond the informal pilot phase was difficult, especially the revision of the manual. She explains, "It was a bit painful. It took a long time to get it into the right shape."

Overall, however, the pilots confirmed that the men were interested and that the methodology was effective. Participants reported that relationships with their children had deepened, that they were less likely to erupt in anger, and that they felt more powerful in solving their problems through cooperation and mutual support. For example, the glass workers formed a children's library at the union building. This was no small achievement. By late 1998, AÇEV's Father Support Program was a viable entity. 


\section{Current Program Staff}

The staff members of the Father Support team stand out immediately for their camaraderie and seriousness of purpose. The culture of teamwork is fostered by Hasan Deniz, who has been the Program Coordinator since 2003 (he joined the program in 2002 and spent one year as an Education Specialist). Hasan explains how he arrived at the program:

Since I graduated from the university, I have worked at NGOS, but AÇEV's mission-especially working with fathers-attracted my attention because my own relationship with my father was good and was so important to me. My father was not an educated man; he was a tailor. Our relationship with him was based on trust, love, and kindness. Whatever he did, he involved me. He would be very happy to see what I do if he were alive. Somehow I am here to fill the gap I feel from losing my father.

In my life, I have witnessed bad consequences where the father-son relationship is disturbed. Many times, I have seen fathers and sons, and I wished inside that the father could just listen to his son, understand the child's feelings, and talk to him differently.

As a whole program, I thought this can give me, metaphorically speaking, a magical tool to intervene in that moment. It is not magical, but it really does give us this power, because when we reach fathers, we can stop the aggression. That is why I am here.

Cem Kaya participated in a ten-day training of trainers and became a volunteer group leader. Says Cem: "I conducted five groups and saw how much it contributed. I liked what the program gave to society and to parents. I volunteered from 1999 to 2004, and then joined the staff as an Education Specialist." In his new role, Cem is responsible for strengthening the training and supervision of group leaders.

Aysen Akgül, the only woman on the team, is responsible for data management and logistics for the Father Support Program. She also assists the team during the training of trainers.

Deniz Doğruöz (coauthor of this report) joined the team in 2007 as an Education Specialist. He is responsible for strengthening the training and supervision of group leaders.

Staff describe their working culture as democratic, cooperative, reflecting the principles that characterize the curriculum. Everyone on staff is given opportunities for leadership.

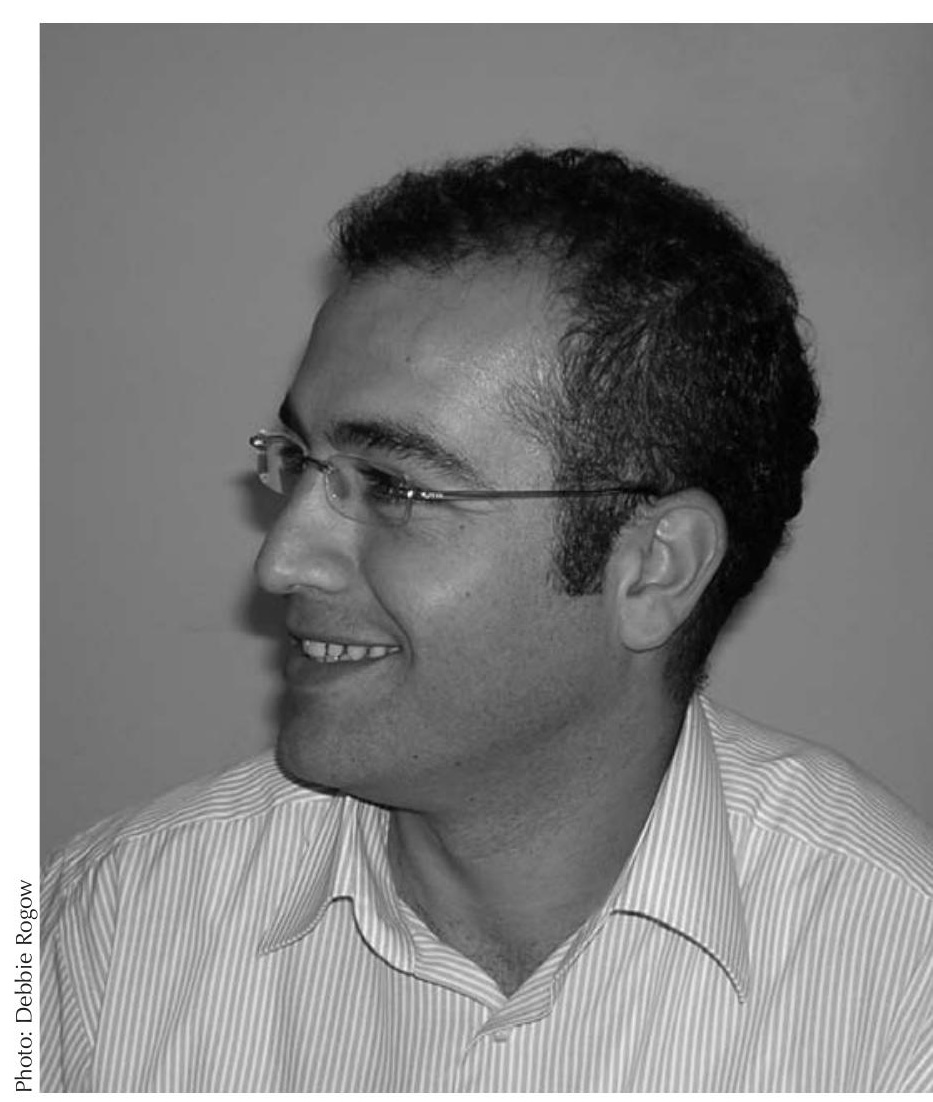

Pictured above is Education Specialist Cem Kaya, who focuses on training and supervision of group leaders. According to Cem, "There is a strong sense of family in Turkey. But as women enter the workforce, fathers want to know, 'How can I rear my kids well?'" 


\section{Recruiting Fathers}

As school counselors, the group leaders were well positioned to recruit fathers. Typically, they sent a letter inviting parents of the students to a meeting. At the meeting, they explained the highly unusual opportunity and the serious commitment associated with program participation. Yusuf Akhan, a barber, recalls the initial meeting:

The person in front (who turned out to be our group leader) said, "We told 400 people about this and 150 have come." I was thinking that it was a normal school meeting. Then he told us about the Father Support Program, that the program required that we dedicate our time and our hearts for 13 weeks, that attendance was obligatory. Half the crowd left immediately. Then the group leader reinforced the commitment, and more people wavered. Finally, he divided the 37 men into two groups: one to meet on a weekday evening and one on weekends. I was in the weekend group. I didn't miss a single session.

Signing up for 13 weekly sessions is not a minor commitment. Derya Akalın points out:

Men with sporadic work schedules are taking critical time from their daily lives and schedules to participate. They could be at the coffee house, working, or watching football.

Several fathers expressed their initial motivation for enrolling in the program:

The common problem in our group was that we fathers could not communicate with our children.

— Sevan Akdemir, goldsmith

We were told that if we participated, our relationship with our children would improve. This affected me.

- Nihat Aydın

In my social life and at work my friends teased me about the program. Our community doesn't accept such things;

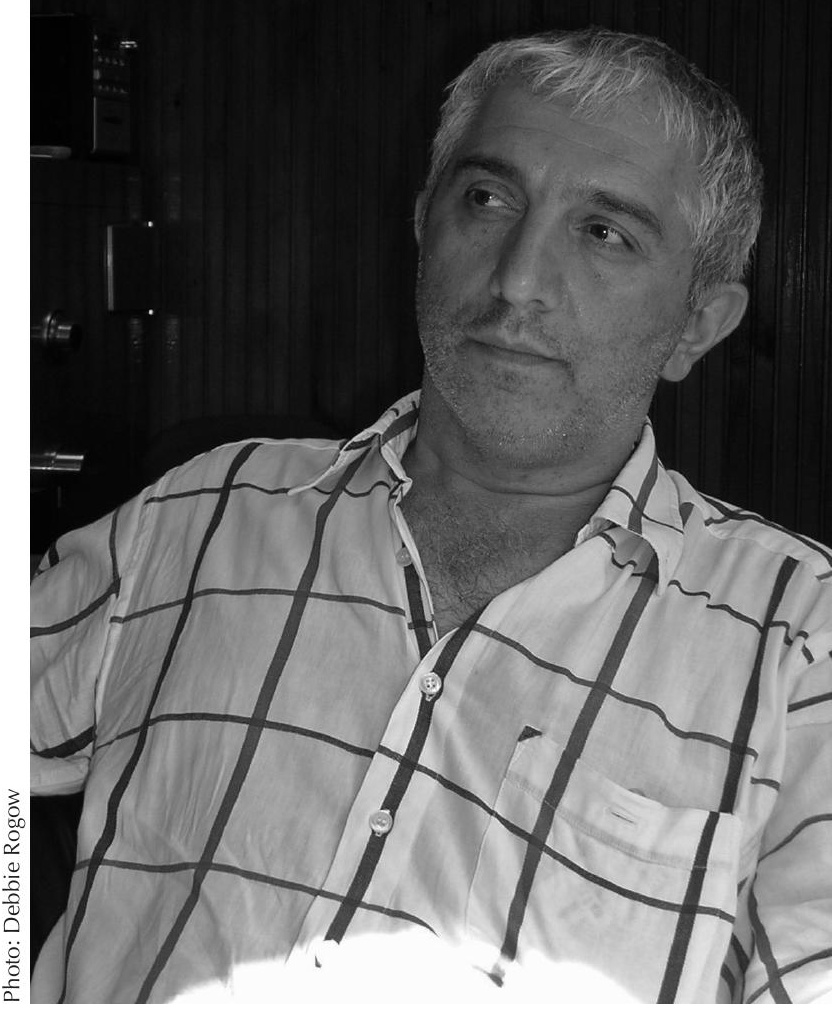

Most fathers are recruited through their children's school, but some come through word of mouth. Kenan Erzurumluoğlu joined together with his longtime friend Sevan Akdemir.

they think we know these things automatically from our culture. In Turkey, women can share things among themselves, but some men don't share family problems with other men. I didn't take the teasing seriously. This is something that I believe in from my heart. My problem is my problem, with my family. So I carried on.

— Yusuf Akhan

[I went] for my children, for their futures, and so they might contribute to humanity. I wanted to learn effective ways to bring them up. I went to develop myself, to learn more.

— Emin Turan, steel-industry employee

Kenan Erzurumluoğlu responded more to others in his decision:

A guidance counselor at my kids' school asked me to help organize a group. I'm on the board of the Armenian church, so I know Sevan-we're friends since childhood here in Istanbul-so we attended the Father Support Program together. 


\section{Program Content}

The curriculum emphasizes children's needs and the skills a father needs to respond effectively. This includes 13 sessions, homework, and attention to group cohesion. At times, the program has included extra sessions on sexual and reproductive health.

\section{Overview of the 13 Sessions}

1. Opening Meeting: Establishing a Contract In the first meeting, fathers share what they hope to gain from the program. This meeting establishes the group dynamic and addresses potential obstacles to participation. Time is also set aside to discuss meeting times and other logistical matters.

\section{Impact of the Father's Role on the Child} Fathers reflect on their role in their child's development. They begin by recalling memories of their own fathers. They are asked "What kind of person did your father want you to be?" and "What kind of person do you want your child to be?" They discuss and compare their fathers' expectations and their own expectations of their children. Finally, they discuss what they can do to support their child's development during the coming week.

\section{Parenting Styles}

This session aims to raise fathers' awareness of their own parenting styles (authoritarian or permissive), and the effects of these styles. The group leader explains that a basic goal of child rearing is to help children gain inner control, and that this goal can only be accomplished by means of a democratic parenting style.

\section{Accepting the Child; Active Listening}

This session explores communication techniques, including a role-playing activity designed to practice active listening. Fathers discuss the importance of basic acceptance of a child.

\section{Using "I" Language}

The objective of this session is to help fathers to recognize their own emotions, thoughts, and desires, and to learn the methods they can use to express themselves effectively with their children.

6. Methods of Positive Discipline (Session I) Group leaders describe positive discipline methods that fathers can use to change their children's undesirable behaviors and help them acquire desirable behaviors.

7. Methods of Positive Discipline (Session II) Fathers discuss the value of boundaries or rules and of experiencing the consequences of one's behavior. Group leaders offer information and activities to demonstrate how to implement these principles. The fathers learn that conflicts are natural and that the best way of resolving conflicts with a child is through dialogue to reach an agreement.

\section{Overview of Child Development}

Group leaders present an overview of children's developmental characteristics and physical developmental stages, and fathers discuss how they can support the physical development of their children.

\section{Cognitive Development and Reading} Group leaders describe cognitive development and how fathers can support the cognitive development of their children. Participants learn how reading contributes to a child's development and are taught techniques to encourage their children to acquire reading habits.

\section{Social Development of Children}

Fathers learn about how children become aware of themselves and others and develop socially appropriate behaviors. In this session, two fathers enact roles in which one behaves sociably, smiling and greeting others when he enters the room. The other hits the door when he enters the room, greets no one, and makes no eye contact. The group discusses the characteristics of sociable and unsociable children.

\section{Emotional Development of Children} Fathers learn ways to become sensitive to their children's feelings and to allow them to express these feelings. This session stresses the development of a child's self-sufficient personality and sense of gender and sexual identity. The fathers also receive materials that enable them to answer children's questions about sexuality appropriately and with tact and understanding.

\section{The Importance of Play}

The significant role that play has in child development is emphasized in this session. Written materials and activities provided to the fathers reinforce the message that playing together with their children strengthens the parent-child relationship and supports children's development.

\section{Applying Attitudes and Skills}

Group leaders explain how participants can also apply program lessons to their adult relationships. The session closes with the "Love Bombardment" activity, reinforcing the positive feelings among the fathers. 


\section{Homework: Practicing a New Approach}

At the end of every session, fathers are given forms to fill out during the week that help them to reinforce the skills they have just learned. For example, the form fathers receive at the end of the session on parenting styles is composed of three parts. The first part asks the participant about his child's behavior. The second part asks about his wife's responses, and about her parenting style. In the last section, the father is asked to write about his reaction to his child's behavior and to identify his own parenting style. If fathers do not return the observation form for the week it covers, they are encouraged to share their observations for the previous week.

\section{Perhaps the most important}

moment comes early, when

participants reflect on their

feelings about how their own

fathers treated them. one another, but the more entertaining activities also unify them. Group leader Sami Erdogan gives an example:

In one exercise, we had a treasure hunt for a book. The fathers really wanted to find the book. But they kept looking around, embarrassed to be seen acting like kids. It was very lively. Later they said, 'We played not as men, but like kids!' Then the fathers each received a copy of the book and set up a treasure hunt at home.

\section{Extra Sessions on Sexual and Reproductive Health}

For a period of time, AÇEV secured funding for the program from the European Union to offer two additional sessions on sexual and reproductive health issues. These sessions also gave the fathers some basic guidelines for peer education. Overall, the fathers were particularly interested in these sessions:

In Turkey, women are blamed if they do not have sons. I learned that the man is responsible genetically for the sex of the child. I also learned about a number of sexually transmitted infections that I did not know about. This program should expand to the rural regions in Turkey.

— Nedim Pörklü, driver

In the sixth week, our group leader announced that he would add two sessions [on sex and reproductive health]. We were shocked. We thought, "In Turkey, this is a tough subject! How can we get into it?" We are more reserved about discussing these topics, maybe because they were not part of our primary-education curriculum. Sometimes we heard older relatives say, "This is taboo, a sin." But no one missed a single session! Even if you know something about it, there are other things you don't know. There were some ques- 
tions and myths. For example, can you get AIDS from sitting on a public toilet? In Turkey, we need opportunities to learn such things-maybe even more than two sessions. The amount of material was huge. There was no time for questions.

There were little booklets. One was designed to educate peers, and the other covered sexual and reproductive health issues. We were told to share the information with at least two others, and I did. Some friends didn't want to take the booklets so they gave it to others to give away. They were from the eastern part of Turkey. Maybe we are conservative and closed, but they were much more so! They said it was a sin to discuss these topics.

- Sevan Akdemir

The sexual health unit gave fathers the task of educating their peers. This is not formal peer-education training, but we tell the fathers they can "share" what they learn. Now (with the loss of funds) we no longer include these extra sessions. But in the session on emotional development, I feel the need to share that family planning information is important and that we used to have this program.

— Ethem Kalyoncuoglu, group leader and supervisor

I expected that the fathers would be shy, but they are eager to learn every minute detail of sex education. We could talk about things that are taboo in society. Also, there were a lot of fathers who buy a specific newspaper and read a column about sexual problems written by a popular Freudian psychiatrist. I was shocked to hear this. They were interested to educate the others, much more interested than we had expected. For example, a policeman asked for ten more booklets to give to his colleagues.

- Olcayto Ezgin

\section{Exploring Paternal Identity}

Over the course of 13 weeks, fathers discuss how their roles are expanding beyond those of provider and disciplinarian. Two fathers reflected on how, later in life,

\section{"When our group leader announced that he would add two sessions [on sex and reproductive health], we were shocked. But no one missed a single session!"}

their own sons would remember them. Sevan Akdemir, a goldsmith, immediately described his hopes: "The most important thing I want my sons to remember about me is that they had a father who worked for their goodness." Dursun Özen considered carefully the character of each of his sons: "The oldest would say: 'He gave his best effort to rear us and to give us what we need.' The youngest is more emotional; he would say: "My father was an open man.'"

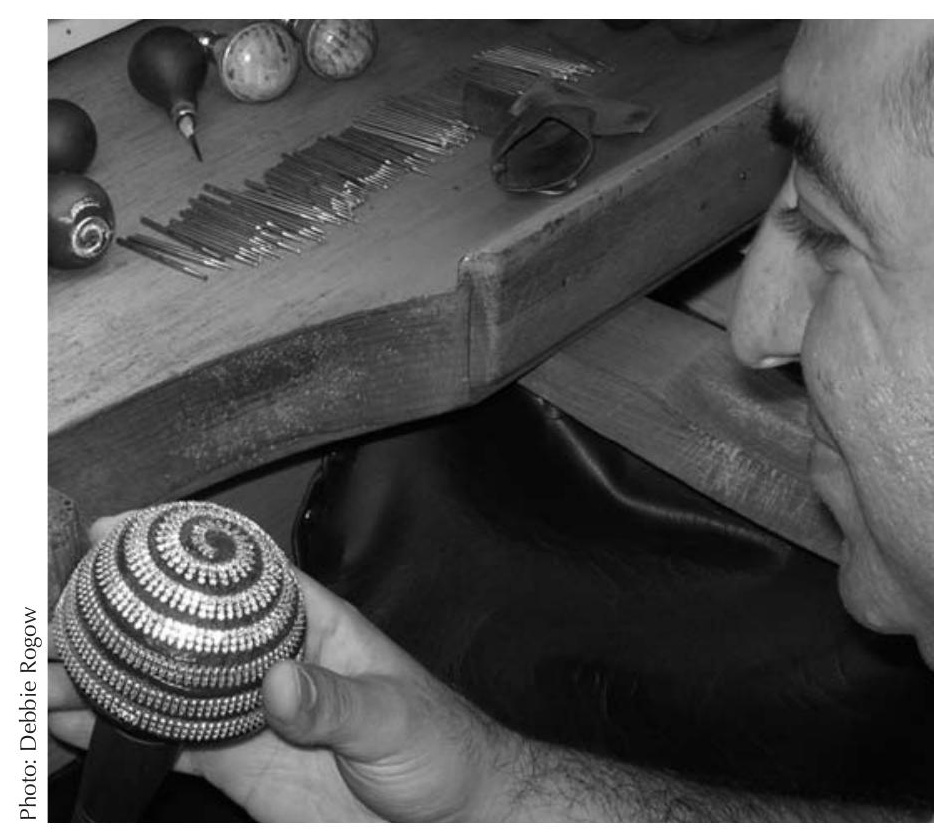

Sevan Akdemir, a goldsmith, shares, "The most important thing I want my sons to remember about me is that they had a father who worked for their goodness." 


\section{The Most Effective Activities}

Fathers, as well as program staff, were asked about their favorite activities. They bubbled over with examples, among which are the following:

\section{Reflecting Upon Our Own Fathers}

The entire program starts with a guided memory exercise. The fathers are asked to reflect on how they feel about one way in which their own fathers treated them. This process produces a great deal of reflection. Fathers spoke immediately and emotionally about this activity (and about their fathers), even in a separate interview with strangers several years later:

My father was distant and insensitive. When I was 14 , I ran away from school. The school wrote him about my absence, and he called me and said "If you do not want to go to school, let me not spend any effort on you." I was not thinking logically, but I felt that he did not care about me.

- Abdi Arda, retiree

My father was an authoritarian who, I believe, had a similar type of father. I could not say, for example, "I want these clothes" or "I do not want those shoes." I had to wear whatever he bought.

— Mustafa Çiçek, insurance agent

He was a great father. It seems that as if he had the Father Support Program training 70 years ago. He raised us with the same democratic method taught in the program. After the training, I wished that I could have spoken with him. He did not know how to read or write, but he knew the democratic way. I want to follow his path.

$$
\text { — Nihat Aydın }
$$

My father had an authoritarian style. A child did not have the right to voice an opinion. I was beaten because of my mistakes. I think my father's generation lacked knowledge of fatherhood. He applied what he had seen from his father.

$$
\text { — Erol Dündar Deveci, group leader }
$$

When I consider what I have now learned, I cannot say that he was a 100-percent good father. He did not spend special time with me and my brother.

— Ali Bahadır, group leader
We did not have much of a relationship with my father. We did not speak with him. He was a nervous and angry man. He beat us when things did not work out as he wished. I did not feel like a child. I did not experience my childhood as our children do.

— Nedim Pörklü, driver

As a young man, my father was trying to make a life in Istanbul. I remember wanting to share quality time with him. But he couldn't spend time with us; he was a steel worker who labored hard. But one time he said, "Come, let's play football." We played all day and I got tired. I was so happy, and I learned. Even though I am fat now, I can still play well, since that day.

- Sami Erdogan

My father took care of farm animals. I was naughty, and he was dominating. His anger was all over him ... he lacked education and cultural orientation to behave differently. His mistake was thinking that aggression was the only way to control us. But I also appreciate him because he taught us to be independent, not to expect too much from others.

— Dursun Özen

The group leader asked us to close our eyes, go to a memory of some bad experience with our father or someone else. I recalled a time I can't forget, even now. He once slapped me on the face. My brother and I had not finished our homework. It is something I cannot forget. As children, these things enter our bodies, and they remain there.

- Sevan Akdemir 


\section{"Apple" - the Importance of Play}

During the eleventh week, the group leader organizes a game called "Apple." The aim is to teach fathers the importance of play for children's development and mental health. The group leader divides the fathers into two groups, and gives each group an apple. He tells them they are seeing this "thing" for the first time. One group is told they can do whatever they want with the apple. The other group is instucted to observe the apple from afar, and to discuss it among themselves. Then the group comes back together to discuss the apple. The first group has touched it, smelled it, perhaps tasted it; they have learned a lot about the apple. The group that has been remote has very little understanding of the apple; they do not even know what it is good for and can take little pleasure in it. Then we ask what happens with children: If we let them touch and experience things, their knowledge is much deeper. Children need to try, to test, and to experience, and the main way they do this is through play.

\section{Listening and Nonverbal Communication}

Several activities are provided to help the fathers understand the factors that influence human communication.

In one exercise, the group leader asks a father to sit on the floor and assigns him the role of the child. Then the group leader stands over the "child" and talks down at him in a scolding voice. Sami Erdogan, a group leader in Ümraniye, demonstrated this simple exercise and explained, "The fathers feel bad. Then we discuss how they communicate with others, with their families and their friends. They remember these activities."

We had a role-playing activity in which the group leader did not listen to me. He did not look at my eyes. I became aware that to be listened to is so important for me. Similarly, if I do not listen to my children when they talk to me, they could feel awful. This affected me.

-Nedim Pörklü

\section{Memories of Physical Force and Punishment}

The group leader asks fathers to recall three memories from their past: (1) an incident in which force was used on them; (2) an incident when they used force on someone else; and (3) a time they witnessed aggression. The fathers then discuss what they remember and how they feel about those memories, first in small groups then later in the large group. Murat Kolay sums up the impact of this exercise: "We felt really small, we felt hate inside. Physical discipline can work in the short term, but it does not create the long-term effect that we hope for. Now, we try to explain things to our children. If our child wants something that is not realistic, we explain the reason. It works."

\section{Valuing Encouragement}

The group is divided into two basketball teams. As they practice, the group leader gives one group lots of encouragement, but criticizes and ridicules the other group. Afterward, they discuss how it felt to be on one team or the other. Murat Kolay reflected: "From this I learned that a child fails because of fear that 'others will criticize me, or make fun of me.' When children are encouraged appropriately for their age, they can experience joy, become successful, and learn easily. In this way, my daughter learned quickly how to ride a bicycle. Now my wife and I have learned to be patient, and we try to protect the nice times, because it is too easy to waste the time when we are together." 


\section{Ongoing Training and Supervision}

When they begin this work, many group leaders worry that they lack sufficient knowledge for their role. But staff are less concerned about knowledge than they are about skills. As Hasan Deniz explains:

The manual contains detailed and specific information and instructions. The group leader can follow that, but he must possess certain skills in applying the participatory methods and in facilitating the activities. The Father Support Program is not about transferring knowledge. It is about sharing experiences to promote reflection, awareness, and behavioral change. For example, we don't say, "Do not beat your child." Ours is more of a Socratic method; we encourage the fathers' awareness and alternatives so that they can reflect. The group leaders see that if they apply

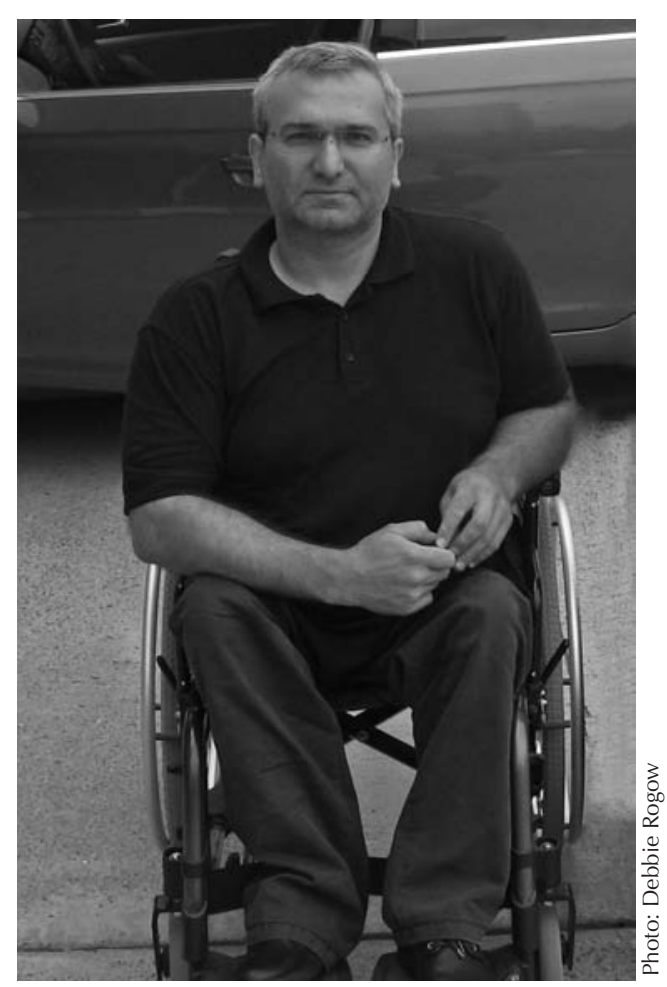

Ali Bahadir, who recalls that his own father did not spend time with him, is a group leader who has found a new set of challenges to address now that his children are teenagers. the methods in the manual, the fathers respond.

A process of ongoing supervision begins shortly after the training of trainers. When the group leader organizes his first fathers' group, a supervisor attends at least three sessions. These supervisors come from the ranks of the more experienced group leaders. They receive minimal payment, working on a freelance basis in addition to their regular jobs. Currently, there are 32 supervisors who supervise approximately 220 group leaders each year. Although the majority of group leaders (and supervisors) live in or near Istanbul, many are based in other cities around the country.

Every autumn, the staff organize a meeting for all of the group leaders in the country. Those who attend exchange experiences, sharpen their skills, and give the staff a chance to get a better sense of what is going on at the "ground" level. These meetings also provide an opportunity for planning the yearly supervision process.

Some group leaders also depend on each other for support. Sami Erdogan, a group leader in Kartal province, explains, "I'm in a phone network of eight to ten other group leaders in the area. We call each other. One guy had a fire in his house; then two days later, his father died. The Father Support Group team organized immediately to help him. This is a natural example of how the program works."

Occasionally, a group leader lacks the skills to be effective, and the staff must intervene. Sometimes they help him to examine the content in greater depth; they also may seek a different role for him so that he is not running the sessions with fathers.

Typically, group leaders organize and run sessions with one or two groups of fathers a year. After two or three years, many find that the time commitment is too demanding and they give up the job. Many others, however, have been running sessions continuously since the program began 12 years ago. 


\section{Results}

By 2007, 533 men had completed training to become group leaders, of whom about 200 are still actively leading groups. A total of 805 groups have been formed, reaching 9,935 fathers and benefiting a greater number of children. Typically, about 75 percent of men who begin the class manage to attend all or most of the 13 sessions.

In 2004, AÇEV conducted a qualitative and quantitative evaluation to assess the program's impact on fathers, and on their wives and children (Koçak 2004).

Most of the respondents ranged in age from 20-50 years; about three-fifths of them were in their thirties. Notably, several grandfathers have also joined Father Support groups. Participants had diverse educational backgrounds: Twenty-eight percent had completed primary school only, 14 percent had completed middle school, 27 percent had finished high school, and 30 percent had graduated from university. ${ }^{2}$ One group leader recalled a group that he led: "We had fathers from all different backgrounds - a writer, a goldsmith, a barber, a tailor, and an unemployed father."

Program results were measured in two ways - through a survey on attitudes and by means of in-depth individual interviews.

\section{Surveying Fathers About Attitudinal Change}

A Likert attitudes survey was developed and administered to 1,379 participants before and after completing the program. The survey included four subscales: adherence to traditional roles, authoritarianism, permissiveness, and communication style. Sample statements in the subscales included:

A child does not obey unless we bawl him out;

The father says the last word at home, A child must be afraid of the father;

A child's cognitive development belongs to the school;

One cannot be angry at what the child does;

Not everything can be shared with the father; and

Comparing your child with others increases your child's success.

Participants responded on a 1-5 scale reflecting total agreement to total disagreement. In this way, each father received an overall score for each factor. Significant differences were found in all the subscale scores, with fathers adopting less traditional and authoritarian attitudes and a more open communication style.

\section{Interviews}

In addition to the survey, 11 fathers and 9 of their wives were interviewed separately in 2007 about their perceptions of the program and its effect on the participant and his family. ${ }^{3}$ The open-ended interviews support the results of the survey, indicating overall positive changes in fathers' attitudes and behavior. In some cases, however, the changes may not have been long-lasting.

Overall, fathers expressed pride in their new understanding of child development and in having done something useful for their children by participating in the program. As Abdi Arda explained, "The most important difference between me and my

\footnotetext{
2 An English version of the evaluation report can be found at http://www.acev.org/english/index.asp.

${ }^{3}$ Eighteen of these fathers and the wives of 12 of them were selected randomly and interviewed separately as part of the 2004 survey. In 2007, as preparation for this case study, an additional 11 fathers and nine wives were interviewed by the authors (including follow-up interviews with several of the respondents who had been interviewed in 2004). Respondents for this latter set of interviews were selected to reflect a diversity of geographic and ethnic communities, socioeconomic classes, and time spent in the program, but represented a convenience rather than a random sample. Because the findings from 2004 and 2007 are similar, they are synthesized here into a single discussion.
} 
father is that I try to be close to my children and monitor their development in life."

Most commented that the interactive format of the program had allowed them to raise questions and share personal experiences. In Istanbul, Nihat Aydın, a father of three girls, noted, "During these sharings, I could see that fathers needed to talk about many topics - being afraid of hugging a newborn baby or feeling worried that an older child would become a gang member." Being able to share with other men is part of what makes these groups so powerful for the participants. As Sevan Akdemir reflected:

The most interesting thing was to see that our problems were more common than we realized. At the beginning, some friends were coming [to the session] even though they had less motivation. But they felt "we cannot leave each other." I missed only one time, because of vacation. Even then, I called in from my holiday.

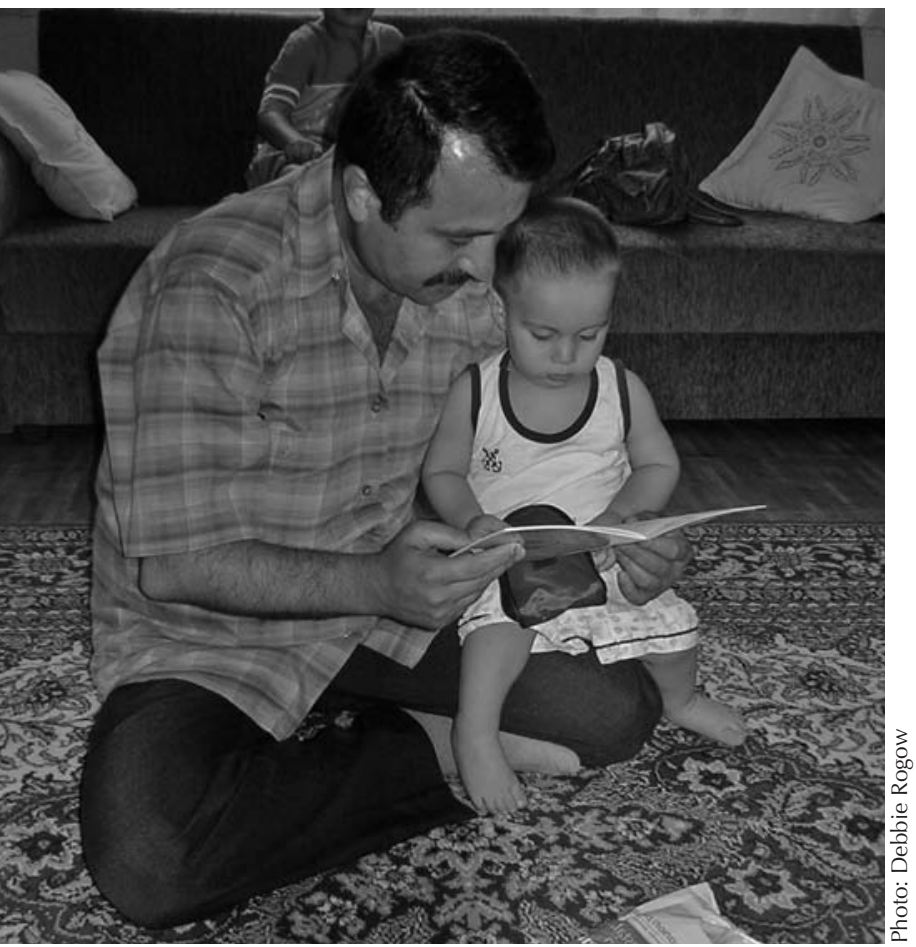

"I had aggressive tendencies, then I was in prison for five years, then I lost my brother to torture. The program helped me become less impulsive and aggressive. Now, even if I feel tense, the tension can fade away. I feel more mature," says Dursun Özen.
In many cases, in addition to a newly developed sense of pride among fathers and better communication with their spouses, the interviews documented behavior changes in the participants' relationships with their children. The most frequently reported changes were in fathers' communication style (especially in listening and discipline) and in time spent with their children (especially in play).

\section{Listening and Discipline}

Fathers reported that they have internalized new communication skills and are able to apply them. Many reported that they now control their anger more effectively, that the group leader taught them that it is more effective to explain rather than scold, and that they now listen to their children. The majority also mentioned that they now use alternative methods of discipline instead of punishing or beating their children as before. They comment that children are often more obedient in response to their new approaches.

Fathers stated that they learned to view their children more fully as individuals, and as a result, have become more thoughtful about what they say to them. For example, they try not to make promises they cannot keep. Consequently children and fathers have become closer. The men reported that they enjoy better communication with others and have become more social.

Before I went to the program, if my child cried or shouted, the only thing that I thought of doing was raising my voice and hands to indicate that I was going to beat her. She would stop. But we were neglecting her needs, we were not thinking of alternatives. Now, I realize that I was making a mistake. I have learned to empathize with my children.

— Murat Kolay, accounting officer

My older son, who is 17, went to a barber shop and got a punk-style haircut, and colored his hair. If I had not gone through the program I would have beaten him. Now, I can tolerate differences in our views. I just said, "What have you done to your hair?" He apologized to 
me, and then he washed his hair! I see that if I listen to him, he can be creative in developing solutions about his life.

I have also used positive discipline methods with the younger one. We are very consistent with rules. If he does not clean up his toys, he knows that he cannot have them the following day.

$$
\text { - Abdi Arda }
$$

We grew up with nothing, nothing. Now, the tendency in our [Armenian] community is to respond to our children's demands. We don't want them to cry, or to lag behind others. We learned that if we give the children everything they want, they will be hurt later, if they do not have resources.

\section{— Kenan Erzurumluoglu}

When I shouted, the problems were covered up or put aside. That did not solve them. I've become much more patient with my wife and child. I finally learned to listen.

$$
\text { —Yusuf Akhan }
$$

Mothers who were interviewed corroborated these reports, saying that their husbands had learned to control their anger and had stopped beating the children, and that they had learned to communicate with the children. As one mother reported: "Now my son tells me that his father is a super father, that he would not change him for anybody else." Another described the change in her family simply, "My husband became a peaceful man."

My husband spends more time with our children. He became more patient. He is much more mature now as a father. I have learned a lot from him. I also became aware of my mistakes.

— Çiçek, wife of one participant

Before, when he was stressed, he shouted at the children to go to sleep. I also become angry easily. He was already a kind man, but now he even turns off the TV in order pay full attention to the children. So, it helped our communication to become better.

—Nihat Aydın's wife, Duygu Aydın
Some mothers, however, felt that these changes were short-term ones; others complained that their husbands had become too lenient with the children.

\section{Time for Play and Affection}

Almost universally, fathers reported having become more understanding of their children's need for playful activities and for close interaction with them. Moreover, they reported spending more time with

\section{Anecdotal reports suggest that some children start thriving academically with the change in their father's behavior.}

their children and showing them more affection. One father explained, "He is just a child; of course he will play, run, jump, and make noise. Now I am more tolerant." Another added, "Now I spend more time with my daughter. I take her to the theater. I try to encourage her." A third father, Yusuf Akhan, shares his view of the challenge:

There is a kind of faulty logic in society: to buy a computer for our child so he can play and leave us alone. My goal is to be with my child to solve problems together.

\section{Academic Improvement}

Group leaders who are also guidance counselors at primary schools hear anecdotal reports about children thriving academically when their fathers change. For example, Nedim, a driver, shared an experience he had when walking down the street and meeting his son's teacher, who was with her dog. The teacher told Nedim that his son had changed dramatically: He was performing well academically, attentive, and engaged, and that his relationship with authority figures had improved. Nedim recalls the source of this change, "My son's school performance immediately increased with my participation in the Father Support Program." 


\section{Fathers' Suggestions for Improvement}

Participants were also asked how the program could be improved. The most frequent suggestions were not about the content; rather, they were to extend its duration beyond 13 weeks and to increase outreach to have a wider impact. Some participants thought it was necessary to include the whole family in the program, because the information it provides is relevant for everyone. They clarified their view, however, that husbands and wives should discuss the same topics but in separate groups. As Yusuf Akhan commented, "At first, it was hard to share what I learned,

\section{Some group leaders are shocked}

when they see the effect of the

program, of their own impact on the fathers.

and my wife felt bad. When I became very patient with our son, it was problematic for my wife. Then she went to the Mother Support Program. The mother and the father should participate together."

Some men suggested aiming the program more intensely toward fathers of very young children, stating that they wish they could have attended when their own children were younger. Others emphasized the importance of forming groups according to narrower age ranges of their children.

Several participants mentioned that they would have liked greater social support for participation (one reported being ridiculed for joining). They suggested that wider promotion of the program is necessary for fostering support of those fathers who participate and for increasing engagement, especially among the most conservative men.

Most of the fathers express enormous respect for their group leaders, typically citing both the leader's knowledge and his ability to form close relationships with participants. A few fathers, however, felt that their group leader lacked crucial knowledge or (in the case of some leaders who are not fathers) experience. Participants' attitude toward the group leader (and sometimes toward a domineering participant) exerted a major influence on their decisions to continue or drop out of the program.

\section{Group Leaders Grow As Well}

Hasan Deniz, Program Coordinator, explains what is so empowering for many of the group leaders: "The most interesting thing I have seen is that some group leaders are shocked when they see the effect of the program, of their own impact on the fathers." Indeed, group leaders feel gratified by the deep respect and trust the fathers put in them. Halis Bilen explained, "I was impressed with the fact that fathers were coming to my group after [long and physically heavy work shifts]. Their response motivated me to do my best."

Another group leader, who worked as a primary-school principal, said that he had learned to express tender feelings toward children. Previously, he felt it would "spoil" the students to tell them that he loved them. After working with the Father Support Program, he stood in front of his schoolchildren and told them that he loves every one of them, regardless of their grades; the students broke into applause. He commented, "Now I understand that when you give love you receive love."

A group leader in Istanbul proudly described the program graduation ceremony in Izmit: "The fathers usually show me to their children and say, 'I participated in this man's group.' The children stare at me and as if to say, 'How is this possible? Is he the man who changed my father?'"

Ethem Kalyoncuoglu has been a group leader since the program began in 1999 . He says:

I learn something from every group. But what I like best is when we read stories 
or anecdotes at the close of each session. It compresses what we want from that week in a small moment. It has an emotional effect, and on my own emotions, too.

One thing that changed me was the sessions on sexuality. I was trained but still afraid the discussion would get out of hand, become crude. I asked for help from my own supervisor; he led the group with me and this helped me. One objective of the unit is to help fathers understand sexuality and how to explain it to their kids. At the time, two of my three sons were teenagers and one was 11 . I realized that I hadn't spoken to my own sons about sexuality! So despite my wife's taboo, I began talking about this issue at home.

Ethem takes great pride in having left a mark on so many men's lives:

I still have a lot of ongoing contact with my former participants. I have worked with 160 fathers to date, of whom 120 completed the sessions. I also conduct outreach sessions. I believe very deeply in this program.

For Olcayto Ezgin, evidence of effectiveness was critical to feeling satisfaction:

The immediate, concrete, and visible effects of the program motivated me to continue to organize groups. Hearing from the participants' children and their wives was important for me.

Group leader Sami Erdogan draws meaning at both the professional and personal levels:

The program provided technical support but it also brought people together. Having community support is typical for the culture, but the program provides a warm connection for men with a developed caring capacity

Also, my relationship with my own wife changed. We learned to look at ourselves, and we developed new ways of being in the family.

Serkan Kahyaoglu, who helped to revise the program, reflects on how he has grown from his association with the Father Support Program: "Every moment, we work with the things that are most important to peoplewith deep, emotionally loaded messages. Being able to think deeply, to experience these moments, gives me pleasure."

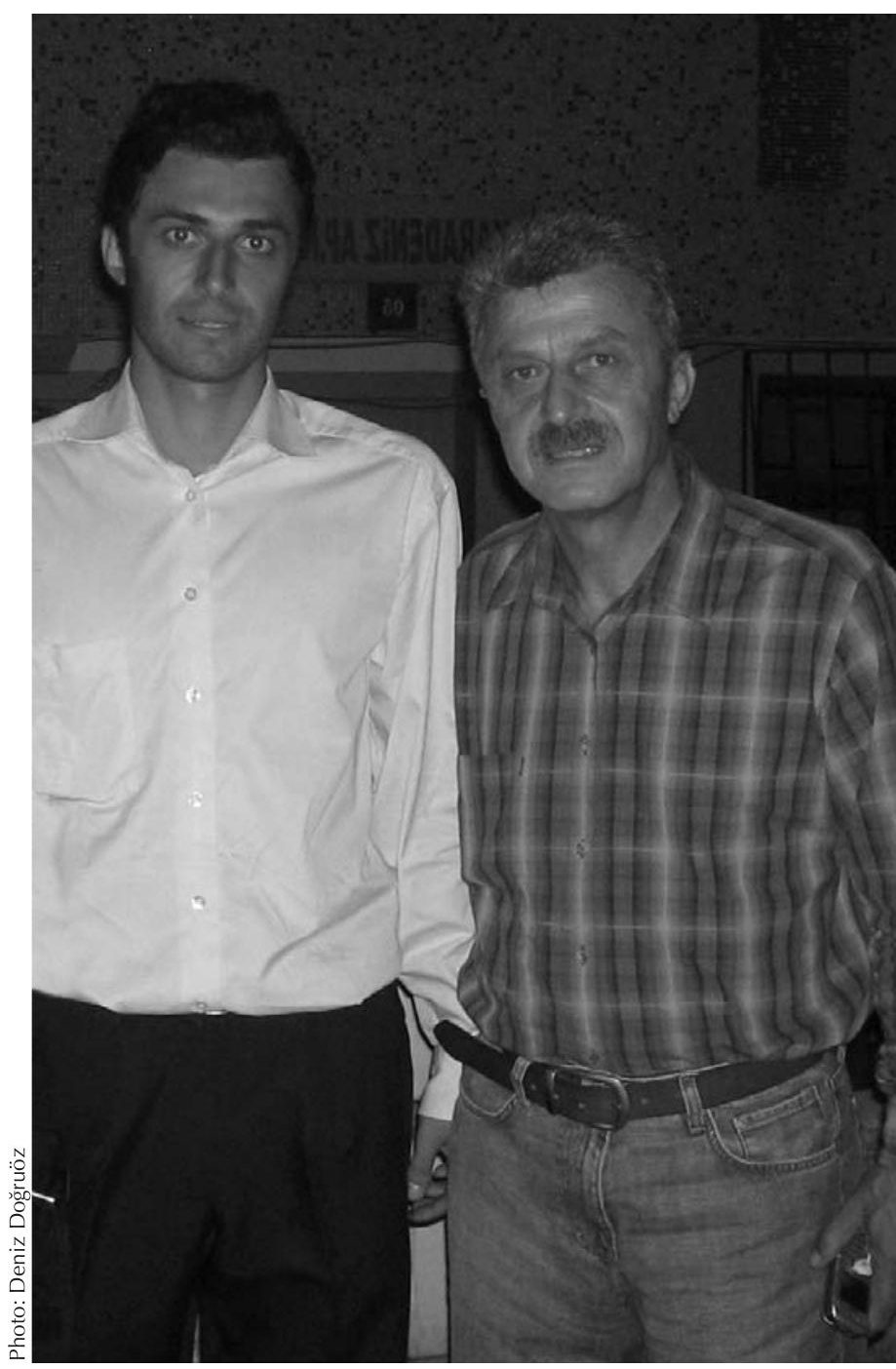

Ethem Kalyoncuoglu (right, pictured with his son) has been a group leader since 1999. Concerned that the sexuality discussions might become crude, he requested help from his supervisor. He also realized that he hadn't spoken to his own teenage sons about sexuality. He says, "This changed me ... I began to talk about this issue at home." 


\section{Challenges: Past, Present, and Future}

The Father Support Program has faced-and continues to face-its share of difficulties and limitations. These challenges are of three basic kinds: cultural, educational, and administrative.

\section{Cultural Challenges: Gender}

The staff have developed a cautious approach with regard to gender issues. Promoting more equitable gender relations is not an explicit goal of the program, nor has this outcome been a formal concern in program evaluation. Hasan Deniz explains:

In general, we encourage fathers to "go deep" into their values; when we train group leaders, the most important skill we want them to learn is to help the fathers reflect deeply so that we can "interfere" with their accepted thinking. But we do not do this directly with regard to gender; we do not promote a radical change in gender roles. Instead, we keep our focus on the father-child relationship. In fact we prepare our program carefully to prevent gender conflicts from emerging directly.

Staff manage, nevertheless, to address the topic of gender in two main ways. First is by intervening in the way that fathers view their girls and boys. The group leaders emphasize that daughters and sons have the same needs, including the need to be supported in their development. Group leader Olcayto Ezgin describes an activity in which fathers reflect on the leisure time they spend with their friends at coffee houses (a common activity among men). They realize that spending even a short time with their children after dinner-

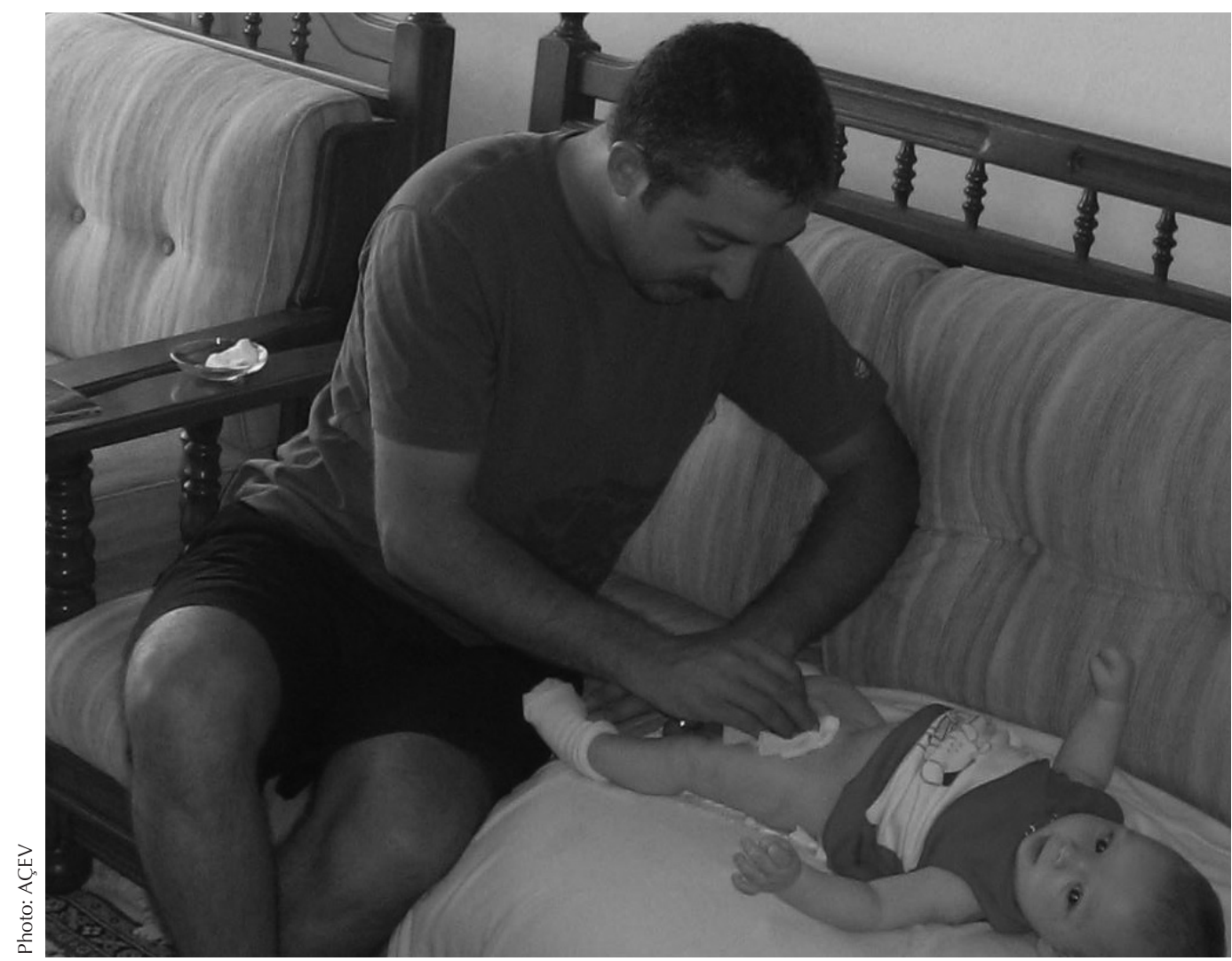

The Father Support Program seeks to change fathers" "job description"—reducing the burden of work for mothers and making children feel loved. 
a departure from the pattern of their fathers' generation-makes an important contribution to their family.

Second, the staff try delicately to open a window onto the issue of husband-wife relations. ${ }^{4}$ According to Serkan Kahyaoglu, "We do not intervene specifically on the theme of gender roles, but we talk about having an environment at home in which the expression of everyone's emotions and thoughts is important. We emphasize that the nature of communication between parents influences the child." Serkan argues that the ethos characterizing the program extends implicitly to the men's relationships with their wives.

For example, one important area within the curriculum is fathers' involvement in child care. Hasam mentions, "We have seen some fathers who insist, 'My father did not do this! It is the mother's job to care for children!'" However, as Serkan explains, fathers in the program develop greater respect for the childcare and domestic work that women have always done and begin to share in these responsibilities. Hasan comments that some fathers have begun to enter the kitchen. Some prepare lunch for their children. As one wife reported, "One night I heard noises coming from the kitchen and I thought it must be a thief. Then, I saw my husband washing the dishes. I could not believe it."

The group leaders also urge fathers to share what they learn with a respectful and "democratic" attitude toward their wives. For example, within the module on positive discipline, fathers are asked, "How can you support your wife? How can you encourage her?" Serkan reports, "A man who tended to shout at and even beat his wife may stop; he begins to show respect for her work and her efforts. The child also gets the message that the mother is valued." ${ }^{5}$

The emphasis, however, is on fathers learning to manage their anger toward their children, and as Sevda Bekman reflects, "Some might still be exercising violence, channelling their frustrations toward their wives. We don't really know.." ${ }^{6}$ The fathers' rapid learning curve may exacerbate familial tensions, moreover. As the fathers become convinced to try new approaches to parenting, they occasionally become critical of their wives' "errors." Such behavior makes their wives feel ignorant or resentful of their husbands' scolding and sudden expertise in what previously had been their domain.

Recently, AÇEV has become more engaged with gender issues in its women's programming, and the staff hope also to integrate this perspective into the Father Support Program. They recognize that this will be a sensitive task, but increasingly they view it as being in line with their goal of supportiong democratic parenting in Turkey. Recalling that the more conservative fathers sometimes shied away from discussing sexual health issues, Derya Akalın cautions, "Every step needs to be managed carefully. It requires a devoted team to handle these difficult political and cultural issues." ${ }^{7}$ One plan is to start an awareness campaign about "masculinity," as an issue that is closely linked to parenting style. This campaign will promote reflection among men about shared childrearing responsibility, domestic violence, and communication with their wives.

\footnotetext{
4 Turkey recently reformed both its penal code and civil codes, establishing greater recognition of women's rights.

5 Some wives, but by no means all, also participate in the Mother Support Program.

6 According to Bekman, gender-based violence appears to be less tightly linked to alcohol in Turkey than in other countries. The consequences of alcohol use have not been enough of an issue to prioritize it at the program level. However, staff have handled some cases individually.

7 By tackling gender issues indirectly, the program has managed to escape criticism from conservative forces in Turkey. In fact, the one example the staff cited of intervention from religious leaders came in the form of support. One time, a Group Leader asked how a child feels when he or she is beaten, and an Imam interrupted in Arabic to say, "Yes, it says that in the Koran that a child feels bad if beaten."
} 


\section{Educational Challenges}

\section{Strengthening Content}

Aside from expanding the program's reach, the other primary focus for the future revolves around improving the program content. For example, Serkan Kahyaoğlu believes the program should emphasize changing the gender roles in Turkish society directly. In a related vein, Sevda Bekman would like to see the program address the issue of violence in the family, not just in relation to the child. She admits, however, that "this is a very sensitive area. It could become something different from what we started out to do."

\section{What [fathers] most remember} are the needs that can meet most simply: spending time with their children, listening to them, and not hitting them.

Bekman also suggests that greater emphasis could be placed on helping fathers to apply what they learn to relationships outside of the family. She points out that children would benefit from seeing their father behave differently in a range of contexts. She also suggests that the program should sponsor special activities for fathers and their children (and perhaps mothers) to attend together. She recalled, "We tried an arts-and-crafts activity. It went well. But sustaining such activities requires materials, clean-up staff, permission from schools, training, and supervision."

Serkan Kahyaoglu believes that fathers need more information about child development and behavior. For example, he notes, "Sometimes, fathers think that when they use "I" language, the child will change automatically. But usually that does not happen. Also we need to be clearer with fathers on how to set rules and limits for their children."

\section{Retaining Learning}

Over the course of 13 weeks, fathers learn about aspects of child development, about parenting skills, about themselves, and about each other. Afterward, little opportunity exists for their new knowledge to be sustained. Hasan Deniz, the General Coordinator of the program, admits, "The fathers lose half of what they learn." He says what they most remember are the needs that they can meet most simply: spend time with their children, listen to them, and do not hit them.

Absenteeism can also limit what some fathers glean from the program. Some miss sessions, and attendance tends to decline over the 13 weeks. With the potentially overwhelming amount of information the program offers, the difficulty of retaining so much information, and the sheer practical demand of attending a class for more than three months, Hasan has renewed discussions about shortening the program.

Even the group leaders do not always have the time to prepare optimally. Ideally, new trainees first participate in the full 13week program as participant-observers before going through a training of trainers. However, pressure from AÇEV's partners to expand the number of groups has meant that the training period has shortened; now only about half complete this step before becoming group leaders.

Finally, the program supervisors may become aware that a particular trainee is not competent. Staff may take him aside and give him further training and guidance, but often they are able to steer him toward other activities that he can carry out in support of the program. Because these men are volunteering their time both for taking the training and for organizing and leading groups, a great deal of sensitivity is required to protect both the quality of the program and its goodwill among men in the community. 


\section{Administrative Challenges}

\section{Expanding Program Reach}

AÇEV continues to expand the audience and scale of the program. Of course, as Sevda Bekman admits, "To implement the Father Support Program on a large scale, we need funds and we need to find the right partners."

The staff members hardly lack for ideas. Bekman spoke of the need for adapting the program for fathers who have low educational attainment and live in rural areas. Such a program would complement existing programs for barely literate mothers, for example, in southeast Turkey. She also expressed interest in reaching men who are about to become fathers for the first time, commenting, "All the theories say that the earlier the intervention, the better the outcome! We tried reaching expectant fathers once, but it means developing a new program, with new partners. ${ }^{8}$ It would be wonderful, but it is a commitment and would require a decision from AÇEV as a foundation."

Hasan Deniz shared an idea about using the mass media to expand program reach: "We want to raise awareness about fatherhood issues across the country. For example, last year we aired an eightweek program on a national television channel. The program was called 'Being a Father Is a Nice Thing.' Each week, we had a different famous person-an artist, a successful businessman, and so forthas a role model. We hope to conduct another television campaign in the near future." Another idea that interests us is reaching men through talks at coffee houses.

\section{Funding and Partnerships}

Participation in the Father Support Program is free of charge. Although the group leaders are volunteers, AÇEV must generate adequate funds to cover staff salaries; the tenday residential training of trainers; the symbolic payments allocated for supervisors; direct expenses for refreshments, printing, and other program operations; and the the annual group leader meetings.

Currently, the program draws funds from two primary sources: core unrestricted funds (of which a substantial proportion comes directly from the Board) and the Ministry of Education (which provides the building and electricity for the school buildings where sessions are held, as well as stipends to reimburse group leaders). On occasion, other donors have contributed to the program. For example, a Turkish retail chain and a Turkish bank have both made contributions for Fathers' Day activities.

Dependence on partnerships with other agencies (as sources of both teachers and fathers) sometimes threatens the program's stability. In 2003, the teachers' union decided to direct its resources to another priority. Many individual teachers, however, continued to work as group leaders on their own. The staff worked hard to develop cooperative relationships with new partners. Recently, the primary partnerships have been with the state-specifically, the Ministry of Education (the Subdirectorates in Primary Education and in Nonformal Education); the Ministry of Health (for the supplementary sexual and reproductive health sessions); and with local governments. Those teachers involved through the Ministry of Education are paid by the Ministry for their services.

8 AÇEV has a program for expectant mothers, but few women bring their husbands to the sessions. Bekman notes that husbands' involvement in pregnancy and birth has caught on in more middle- and upper-class settings; in urban areas, educated men often attend their children's births. In low-income communities, however, customs related to birth typically exclude the father. 


\section{Conclusion}

Among the most striking characteristics of the Father Support Program are the consequences of having a democratic philosophy in carrying out the work. Despite the program's considerable success, staff continue to bring a self-critical eye to their work. They listen to the supervisors, group leaders, and individual fathers, and they try to adapt the program from year to year.

Second, the staff report that Hasan Deniz manages the team democratically, relying on hierarchies when necessary for efficient functioning, but otherwise fostering a spirit of mutual respect and cooperation. As Hasan explains, "The strongest characteristics of our team are sharing information, transparency, active listening, and the ability to say 'no' honestly to each other, regardless of a person's position on the team." The team generally operates by consensus, and enough space exists for everyone to exercise his initiative. Instead of being solely results-oriented, this approach emphasizes each person's relationship with the group process. Team members often socialize outside the office.

Most fundamentally, the Father Support Program sees democracy as the guiding principle in its work with fathers. Mutual respect, the rights of all human beings in a family, a spirit of intellectual and emotional openness, and nonviolent conflict resolution are the program's central tenets. Many of the specific skills that the program teaches are based on these democratic attitudes and behaviors.

By building democracy within families, of course, the staff are building democracy in Turkish culture, father by father and family by family. It is slow work, but the depth of transformation among the participants is testimony to the power of the Father Support Program's approach. Indeed, when Hasan Deniz was asked to reflect about his biggest mistake with regard to the program, he thought silently, then replied: "I didn't expect that the program could do so much. I had no idea how great the possibilities were."
Yusuf Akhan, whose description of his difficult relationship with his father opened this case study, described how he resolved his feelings of disappointment, and what values now guide his own life as a father.

My father died just before I joined the Father Support Program. I want to tell you something: The happiest moment I've had-but happy and sad together-was when my father spent 15 days in the Intensive Care Unit of the hospital. The nurses called me, and I went.

He was connected to machines, not fully conscious. But he took my hand to his mouth and kissed it. He kept repeating, "Yusuf, Yusuf . . ." The nurse said "Your father loves you a lot. You are lucky." I told her, "I am experiencing this for the first time in my life."

You never experience such expressions of emotion, and then for the first time, he smells you, kisses you. ... You lacked this growing up, you lacked it for years. I was blaming my father all those years for what I had experienced in life. Until that moment.

This was a special moment for me. I was 29. I cried, a lot.

Now I'm happy. I don't have much money. I see that people have lots of money, but they are not happy. To reach happiness, you need a good relationship in the family. The reason I earn money is so that I can have a good life with them. When I am out, I don't buy something just for myself. If I want to eat something outside, I buy it and bring it home and we have it together. This is my definition of a family - to share. No parent wants his or her child to end up in trouble. But we don't spend the effort to solve problems. They say, "I work. I provide money, everything is solved."

I want to live correctly, appropriately. I will not solve 100 percent of my problems, but I believe that the Father Support Program is 100 percent beneficial.

Now we're thinking of having a second child. We'll know what to do this time. 


\section{Lessons Learned}

- Encouraging men to recollect their childhood relationship with their own fathers is a powerful way to begin a process of reflection and growth. Thinking about this relationship allows them to identify with their children, rather than starting out feeling defensive about their own behavior. Remembering their relationship with their fathers also opens them up emotionally, which is central to helping them to respond to the benefits of the entire program.

- Focusing on fathering provides an entree to exploring family relations and masculinity more generally in highly conservative environments. Programs can help men think about shared responsibility, domestic violence, and communication with their wivesand can lead to positive behavior change. Programs must also find the best balance in addressing gender issues: On one hand, interventions should not make participants feel threatened. If, on the other hand, gender equality is not an explicit consideration in designing a program, the program can also produce unintended negative effects on women (for example, their role as experts in parenting decisions may be usurped). Appropriate thought must be given to the effects on gender dynamics in designing and evaluating a program, even if that is not the program's primary goal.

- The volunteer model can be effective. Many programs based on volunteer models result in high turnover and undervaluation of the labor of the (mostly female) volunteers. The Father Support Program has found, however, that group leaders engender greater trust from participants if the leaders are volunteers who are dedicated to the program and its values.

- An underlying commitment to democratic culture at home requires a democratic practice within the program and among the staff. In Gandhi's words, "Be the change you want to see in the world."

\section{References}

Hacettepe University Institute of Population Studies. 2004. Turkey Demographic and Health Survey, 2003. Ankara: Hacettepe University Institute of Population Studies, Ministry of Health General Directorate of Mother and Child Health and Family Planning, State Planning Organization and European Union.

Zahir, Fazil. 2006. "Winning the gender gap war in Turkey." <http://www.ungei.org/infoby country/turkey_895.html>. Accessed 15 January 2009.

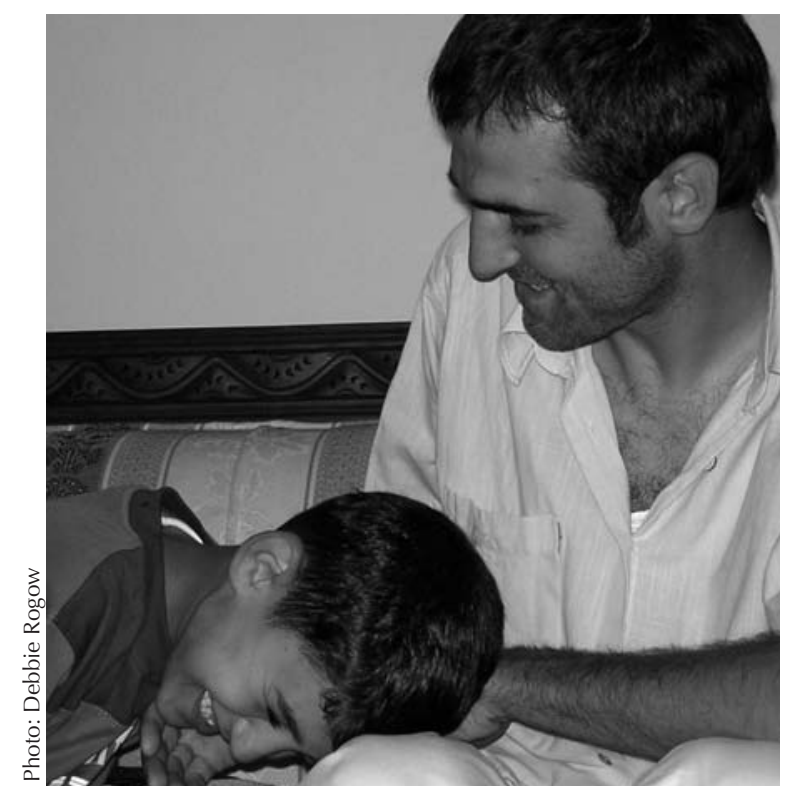




\section{Resumen en Español}

Las cambiantes normas de género y el creciente número de mujeres que trabajan en Turquía han puesto presión sobre los hombres por compartir el cuidado de los hijos de una manera más equitativa. El Programa de Apoyo a Padres de la Fundación para la Educación de Madres e Hijos (AÇEV—Mother Child Education Foundation) tiene el propósito de ayudar a los padres de familia a desempeñar un rol más efectivo en el desarrollo de sus hijos; a reconocer la importancia que tiene su presencia en la vida emocional de sus hijos; y a dedicar tiempo de calidad a convivir con sus hijos. El programa opera grupos de apoyo para padres; estos grupos se reúnen una vez a la semana durante 13 semanas.

El personal recluta orientadores y maestros de escuelas primarias con el propósito de que lideren grupos para padres en forma voluntaria. Los líderes de grupo son capacitados en un taller residencial de 10 días de duración. Este taller pone énfasis en la participación interactiva, temas emocionales y relaciones democráticas; los participantes en la capacitación también reciben un manual detallado para dirigir los grupos de apoyo a padres. El personal también pone énfasis en una cultura democrática dentro del programa.

Como uno de los padres explicó, "[Yo asistí] por mis hijos, por sus futuro y para que ellos puedan contribuir a la humanidad. Yo quería aprender formas efectivas de criarlos".

Las 13 sesiones comienzan enfocando la atención en las experiencias de los padres asistentes con sus propios padres. En sesiones posteriores se explora el desarrollo del niño, los estilos de paternidad, la escucha activa y la comunicación positiva, así como la importancia del juego. También ha habido interés en tópicos de salud sexual y reproductiva. El fortalecimiento de los vínculos de comunicación y confianza entre los padres es también un elemento importante. Como ejemplo, una actividad que produce una profunda reflexión, es en la que los padres recuerdan un momento de su niñez cuando fueron testigos o experimentaron agresión por parte de sus propios padres. Las actividades de escenificación de roles también recuerdan a los padres la forma en que sus hijos se sienten cuando son ridiculizados. Eventualmente, algunos líderes de grupo asumen un rol de supervisión, pero como voluntarios.

A la fecha, casi 10,000 padres de familia han cursado el programa (con cerca de un 75 por ciento habiendo asistido a todas o a la mayoría de las 13 sesiones). De 533 líderes de grupo capacitados, 200 están dirigiendo grupos. Una encuesta de línea de base y postprograma encontró que los padres que completaron el programa se apegan menos a los roles tradicionales, son menos autoritarios, más permisivos y han desarrollado un estilo de comunicación más abierto. Estos hallazgos fueron corroborados mediante entrevistas con los propios padres y con muchas de sus esposas. Entre los comentarios ofrecidos por estos padres de familia están:

"He aprendido a establecer lazos de empatía con mis hijos."

"Si no hubiera cursado el programa, habría golpeado a mi hijo."

"Me he vuelto mucho más paciente con mi esposa y con mi hijo. Finalmente aprendí a escuchar."

"Mi relación con mi esposa cambió. Hemos aprendido a mirarnos a nosotros mismos; desarrollamos nuevas formas de ser parte de la familia."

Los actuales retos incluyen: promover de manera más activa las relaciones respetuosas e igualitarias entre esposos y esposas, sin crear una reacción conservadora en contra del programa, así como repensar la estructura del programa a la luz del hecho de que muchos padres de familia no retienen mucho de su contenido más allá de la importancia de pasar más tiempo con sus hijos y de escucharlos.

Las lecciones aprendidas incluyen: (1) El recuerdo de la relación con los propios padres durante la niñez fomenta la reflexión y el crecimiento. (2) El enfoque en la paternidad proporciona una entrada a la exploración de las relaciones familiares y la masculinidad, aún en entornos conservadores. (3) Un compromiso con la cultura democrática en el hogar, requiere una práctica democrática dentro del programa y entre el personal. 


\section{Résumé en Français}

En Turquie, les normes sexuelles changeantes et le nombre croissant de femmes actives sont à l'origine d'une certaine pression pour que les hommes participent plus équitablement aux soins et à l'éducation des enfants. Le programme de soutien AÇEV vise à aider les pères à assumer un rôle plus concret dans le développement de leurs enfants ; à reconnaître leur importance dans la vie affective de ceux-ci et à passer plus de bons moments avec eux. Le programme organise des groupes de soutien paternel. Ces groupes se réunissent 13 fois, à raison d'une fois par semaine.

Le personnel du programme recrute dans les écoles primaires des conseillers d'orientation et des enseignants de sexe masculin, qui acceptent bénévolement de guider les groupes de pères. Ces animateurs sont formés dans le cadre d'un atelier résidentiel de 10 jours. L'atelier met I'accent sur la participation interactive, les thèmes affectifs et les rapports démocratiques. Les participants reçoivent un manuel détaillé sur la manière d'animer les groupes de soutien. Le personnel fait aussi valoir les principes $d^{\prime} u n e$ culture démocratique au sein du programme.

Comme l'a expliqué un père: " [J'y suis allé] pour mes enfants, pour leur avenir et pour qu'ils puissent contribuer à I'humanité. Je voulais apprendre des moyens efficaces de les élever. »

Les 13 séances commencent par un regard sur l'expérience vécue par les participants avec leur propre père. Le programme évolue ensuite vers l'exploration du développement de l'enfant, les styles d'éducation, l'écoute active et la communication positive, et l'importance du jeu. Les questions de santé sexuelle et génésique éveillent aussi un certain intérêt. L'établissement de bonnes relations entre les pères représente un autre aspect important du programme. Une activité type, où les pères évoquent un moment de leur enfance où ils ont eux-mêmes observé ou subi l'agressivité de leur propre père, suscite une profonde réflexion. Des jeux de rôle rappellent aux pères I'effet de la dérision sur les enfants. Certains animateurs finissent par assumer un rôle d'encadrement, mais toujours à titre bénévole.

Près de 10000 pères ont à ce jour participé au programme (environ $75 \%$ assistent à toutes ou à la plupart des 13 séances). Sur 533 animateurs formés, 200 dirigent aujourd'hui les groupes. Une enquête de base et post-programme a révélé que les pères qui achèvent le programme adhèrent moins aux rôles traditionnels, sont moins autoritaires, plus permissifs et qu'ils ont développé un style de communication plus ouvert. Les entretiens avec les pères et avec beaucoup d'épouses viennent corroborer ces observations. On citera, parmi les commentaires reçus des pères :

" J'ai appris à mieux ressentir, par empathie, ce que ressentent mes enfants. »

«Si je n'avais pas participé à ce programme, j'aurais battu mon fils. »

" Je suis devenu beaucoup plus patient à l'égard de ma femme et de mon enfant. J'ai enfin appris à écouter. »

«Ma relation avec ma femme a changé.

Nous avons appris à nous regarder nousmêmes ; nous avons développé de nouvelles façons d'être dans la famille. »

Les défis actuels sont les suivants: promouvoir plus activement les relations fondées sur le respect et l'égalité entre maris et femmes sans provoquer de réaction conservatrice à l'encontre du programme ; et repenser la structure du programme à la lumière du fait que beaucoup de pères ne retiennent guère de contenu au-delà de l'importance de passer du temps avec leurs enfants et de les écouter.

Parmi les leçons tirées: (1) Le souvenir de ses rapports d'enfance avec son propre père favorise la réflexion et la croissance. (2) La concentration sur la paternité crée une ouverture sur l'exploration des relations familiales et la masculinité, même dans les milieux conservateurs. (3) L'engagement envers une culture démocratique au foyer exige une pratique démocratique au sein même du programme et parmi son personnel. 


\section{About the Authors}

Gary Barker was formerly the director of Instituto PROMUNDO, a Brazilian organization working with men and boys. He is now Senior Technical Advisor on Gender, Violence, and Rights at the International Center for Research on Women (ICRW).

Deniz Doğruöz is a psychologist and the education specialist at AÇEV (Mother Child Education Foundation).

Debbie Rogow is the editor of $Q / C / Q$. She has been involved in research and various programs relating to masculinity and men's sexual and reproductive health.

\section{Acknowledgments}

The authors wish to acknowledge Nurper Ulkuer at UNICEF for identifying this project. We also thank the fathers and mothers who were interviewed for this article. Finally, we are grateful for the contributions of AÇEV Board Member Sevda Bekman and of various AÇEV staff members, especially Aysen Akgül, who participated in conducting a number of interviews for this publication.

\section{AÇEV (Mother Child Education Foundation)}

Büyükdere Cad. Stad Han. No:85 Kat:2 34387

Mecidiyeköy - İstanbul TÜRKIYE

www.acev.org e-mail: acev@acev.org

We invite your comments on Quality/Calidad/Qualité. If you would like to be included on our mailing list, please send an e-mail to: qcq@popcouncil.org. Most past editions are available online at <www.popcouncil.org/publications/qcq/default.htm $>$. Single or multiple print copies of past editions may be ordered by e-mail.

No. 1 Celebrating Mother and Child on the Fortieth Day: The Sfax Tunisia Postpartum Program, 1989. (E)

No. 2 Man/Hombre/Homme: Meeting Male Reproductive Health Care Needs in Latin America, 1990. (E,S)

No. 3 The Bangladesh Women's Health Coalition, 1991. (E)

No. 4 By and For Women: Involving Women in the Development of Reproductive Health Care Materials, 1992. (E,S)

No. 5 Gente Joven/Young People: A Dialogue on Sexuality with Adolescents in Mexico, 1993. (E,S)

No. 6 The Coletivo: A Feminist Sexuality and Health Collective in Brazil, 1995. (E,P,S)

No. 7 Doing More with Less: The Marie Stopes Clinics of Sierra Leone, 1995. (E)

No. 8 Introducing Sexuality within Family Planning: Three Positive Experiences from Latin America and the Caribbean, 1997. (E,S)

No. 9 Using COPE to Improve Quality of Care: The Experience of the Family Planning Association of Kenya, 1998. (E,S)

No. 10 Alone You Are Nobody, Together We Float: The Manuela Ramos Movement, 2000. (E,S)

No. 11 From Patna to Paris: Providing Safe and Humane Abortion, 2001. (E)

No. 12 Universal Sexuality Education in Mongolia: Educating Today to Protect Tomorrow, 2002. (E)

No. 13 What about Us? Bringing Infertility into Reproductive Health Care, 2002. (E)

No. 14 "My Father Didn't Think This Way": Nigerian Boys Contemplate Gender Equality, 2003. (E,F)

No. 15 Linking Reproductive Health to Social Power: Community Health Workers in Belize and Pakistan, 2004. (E)

No. 16 Healing Wounds, Instilling Hope: The Tanzanian Partnership Against Obstetric Fistula, 2004. $(\mathrm{E}, \mathrm{F}, \mathrm{Sw})$

No. 17 In Our Own Hands: SWAA-Ghana Champions the Female Condom, 2006. (E)

No. 18 Living Up to Their Name: Profamilia Takes on Gender-based Violence, 2006. (E)

$(\mathrm{E})=$ English; $(\mathrm{F})=$ French; $(\mathrm{P})=$ Portuguese;

$(\mathrm{S})=$ Spanish; $(\mathrm{Sw})=$ Swahili 
Quality/Calidad/Qualité/ 